\title{
WestVirginiaUniversity
}

THE RESEARCH REPOSITORY @ WVU

Graduate Theses, Dissertations, and Problem Reports

2001

\section{English in the university of excellence}

Joe Morris

West Virginia University

Follow this and additional works at: https://researchrepository.wvu.edu/etd

\section{Recommended Citation}

Morris, Joe, "English in the university of excellence" (2001). Graduate Theses, Dissertations, and Problem Reports. 707.

https://researchrepository.wvu.edu/etd/707

This Thesis is protected by copyright and/or related rights. It has been brought to you by the The Research Repository @ WVU with permission from the rights-holder(s). You are free to use this Thesis in any way that is permitted by the copyright and related rights legislation that applies to your use. For other uses you must obtain permission from the rights-holder(s) directly, unless additional rights are indicated by a Creative Commons license in the record and/ or on the work itself. This Thesis has been accepted for inclusion in WVU Graduate Theses, Dissertations, and Problem Reports collection by an authorized administrator of The Research Repository @ WVU. For more information, please contact researchrepository@mail.wvu.edu. 
English in the University of Excellence

Joe Morris

Thesis submitted to the College of Arts and Sciences at West Virginia University in partial fulfillment of the requirements for the degree

Master of Arts in English

Brian McHale, D.Phil., Chair

Timothy Sweet, Ph.D.

Cheryl B. Torsney, Ph.D.

Department of English

Morgantown, West Virginia, 2001

\section{Keywords}

Department of English—West Virginia University. Literature-Study and teaching (Higher) — United States.

Martin, Alexander, 1822-1893 - Criticism and interpretation.

Readings, Bill, 1960-1995-Criticism and interpretation.

Copyright 2001 Joe Morris 


\begin{abstract}
"The modern University," according to Bill Readings, "has had three ideas: the Kantian concept of reason, the Humboldtian idea of culture, and now the technobureaucratic notion of excellence." "Excellence" euphemistically describes the principle of the university as corporation, as geared ultimately toward revenue and production rather than ideology. Such a portrayal raises difficult questions for the humanities, as subjective, ideological domains. For instance, How in this scenario might issues of value and judgment be addressed without final recourse to cost-benefit analysis? Taking Readings's The University in Ruins as a starting point, the present study examines the unique fate of the English discipline within the "university of excellence," considering West Virginia University's English department as a case study. It will begin by charting the evolution of WVU's selfunderstanding, from an institution of culture to one of excellence. This will foreground my discussion of two more recent department chapters - the rise of composition and of "theory" — as symptomatic of excellence. The study will conclude by relating Readings's views on how academics might orient themselves to the "ruins" of the university so that it remains above all a space for thinking.
\end{abstract}




\section{Acknowledgments}

A number of people made the completion of this thesis possible. Brian McHale raised the issues that initiated my research, and supplied the feedback that propelled and helped clarify it. Tim Sweet and Cheryl Torsney gave me necessary encouragement. Barbara Patterson took the time to dig up English department documents and guide me along the departmental paper trail. And three former department chairs - Rudolph Almasy, Pat Conner, and Micki Ginsberg — graciously met with me for interviews; each responded with not only a wealth of information but obvious enthusiasm about what I was trying to do. All have my gratitude. 


\section{Table of Contents}

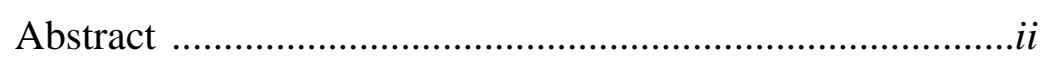

Acknowledgments ..............................................................iii

Chapter 1: Introduction ....................................................

Chapter 2: The University.....................................................

Chapter 3: The Department.....................................................16

Chapter 4: The University in Ruins .........................................33






\section{Chapter 1: Introduction}

The master's student of two hundred years ago would not be writing a thesis. In emulation of the medieval Oxbridge model, the American master's degrees granted throughout the eighteenth century signified nothing so much as sound character, not scholarly accomplishment, and usually preceded a career in the pulpit. They were conferred "as a matter of course" on baccalaureates deemed reputable and who needed only to stay on campus an extra year after graduating. A hundred years ago, conversely, there would almost certainly be a thesis, plus a rigorous exam and lengthy curriculum to complete, largely in accordance with the influential example of the modern German research university. Under that model, the master's represented an "original contribution" to a body of research serviceable to the state and generally led to employment as a schoolteacher or professor. In 2001, it is a tremendous anomaly to either write a thesis or take a comprehensive exam. Were I studying in nearly any other discipline, my curriculum as a master's student would consist primarily of highly specialized professional or "applied" training designed explicitly to secure workplace credentials or readiness and coordinated with professional associations. $\underline{1}$

Such a history makes the master's emblematic of much larger changes in the university, changes which will be the focus of my thesis. The master's neatly encapsulates not just the changes in the university, but also those in the geopolitical structures that have helped define the university. At first an instrument of the church, the university evolved into an extension of the state. And the function of the university, like that of the master's, evolved accordingly: from instruction in social and religious ideology to the propagation and inculcation of national culture. The latest master's incarnation suggests the university has today evolved into an arm of the market, that it has become in effect a corporation. It suggests that the university's mission is no longer involved with adding to a body of knowledge serviceable principally to the state and with training students to identify them selves as Americans. Similarly, it underscores the argument that the expansion of the capitalist world-market has steadily eclipsed the nation-state as a force capable of uniting

1. On the history of master's degree programs in the United States from the eighteenth century, see Glazer 7-14 and Conrad, Haworth, and Millar 3-21. On the rarity of master's theses and comprehensives, see Conrad, Haworth, and Millar 22. On the preponderance of the professional component in master's education, see Conrad, Haworth, and Millar 17 and Glazer, who finds evidence for "a paradigmatic shift" beginning in the early 1970s "from the arts and sciences model to manifold professional degrees":

The dominant paradigm is practitioner-oriented, emphasizing training in skills, career development, and pragmatic goals. It is linked to the needs of the student and the demands of the marketplace and driven by externally imposed standards, and it emphasizes practice rather than theory, skills rather than research, training rather than scholarship.... [Candidates] are... seeking skills that will prepare them for the work force. (83)

The two national studies of master's programs since Glazer's have both affirmed her conclusions specifically. See Conrad and Eagan, and Conrad, Haworth, and Millar 21-3. 
populations and claiming their loyalties.

Especially since the end of the Cold War, Western nation-states have lost almost all interest in the kind of ideological rivalries that made university research, including humanities scholarship, appear not only necessary but urgent. It might seem strange to think of the humanities as serving the military-industrial complex, but the legislation establishing the National Endowment for the Humanities in 1965 makes the connection explicit. 2 Today, of course, the NEH struggles to remain funded at all; and universities too continue to surrender more and more of their state funding. In West Virginia, a law enacted in 1995 has mandated that higher salaries and other new spending at universities be funded through cutbacks in existing spending, applying a zero-sum logic to finance that amounts to an unadjusted spending freeze over the last five years. Additionally, the legislation encourages colleges and universities to search out support from private sources. $\underline{\mathbf{3}}$ Such changes take their place with the introduction of voucher programs into the public school system as further episodes in the erosion of the public sphere and the historical project of national culture.

Since their emergence in the last quarter of the nineteenth century, English departments had always enjoyed a prominent role in that earlier arrangement, as the key repository of cultural values relating to an idealized view of the nation, as the institutional locus of those texts that purportedly adumbrated a tradition that everyone was a part of, that united Americans in one culture. It cannot be a coincidence that literary studies as an academic discipline came into existence with the modern research university, which exists to advance the nation-state. In his study of the development of literature as an academic discipline in the United States, Creating American Civilization (1994), David R. Shumway elaborates the linkage between nationalism and academic literary studies. The discipline in effect "created American civilization," he writes; it "produced a widely accepted representation of American civilization that not only defined its character but

2. From Point 8 of Section 2 of the 1965 legislation: "The world leadership which has come to the United States cannot rest solely upon superior power, wealth, and technology, but must be solidly founded upon worldwide respect and admiration for the Nation's high qualities as a leader in the realm of ideas and of the spirit."

Twenty-four years later, on the occasion of signing the Educational Excellence Act of 1989, President Bush would by contrast justify federal education spending in purely economic terms: "I believe that greater educational achievement promotes sustained economic growth, enhances the Nation's competitive position in world markets, increases productivity, and leads to higher incomes for everyone" (Ohmann xxxii).

3. Senate Bill 547, passed on March 11, 1995, requires West Virginia state colleges and universities to bring salaries more in line with regional benchmarks and carry out other initiatives, but leaves it to the institutions themselves to generate the new funding. According to the legislation, each institution will need to "refocus its mission and leadership and restructure its existing resources and programs to achieve the goals" (18B-1-1c.18-20). More specifically, colleges and universities must "eliminate duplicative programs and services... and eliminate under-utilized or unnecessary programs" (18B-1-1c.37-40). The lawmakers also urged that "[c]loser linkages should be established among higher education and business, labor, government, community and economic development organizations" (18B-1-1a.98-100). 
'verified' its existence" (6). There is no good reason to mourn the loss of such an arrangement, because the pretensions to a representative culture and innocuous "great tradition" that underlay it were all along merely ideological — performative, not constative, and not innocuous. As Shumway explains, "The constitution of American literature as a field served the interests of particular factions within the profession and those of the dominant class, race, and gender within American society. As a result, race, class, and gender bias were structural to the object the discipline constituted in the 1920s, and remained so as the object was reconstituted after World War II" (9). 4 One of the most salutary changes that professionalist education has precipitated since the war, therefore, is that today my classes are populated mainly by women and tend to include members of ethnic minorities, international students, workers, and people over 30, whereas before a strict racial, gender, class, and age homogeneity prevailed. $\underline{\mathbf{5}}$

At the same time, it is hard to envision a place for English, or any meaningful humanities academics, under a professionalist regime. But not, or not only, because English on the face of it has so little to offer the market. Rather because, absent the ideological meaning-giving compasses of the church and nation-state, it is no longer clear what "meaningful humanities academics" might mean or how it might be justified. The question is often framed as one of "legitimation": What makes the study of language and literature - a discipline with little claim on objectivity and little to offer in the way of employment training - a legitimate enterprise for a publicly funded institution? Legitimation has always presented a problem for the institutionalized study of literature, and the humanities in general, as subjective realms (though less so for language); but it was an issue that had been resolved historically by enlisting literature and the humanities in the project of national culture, which endowed them with the quasi-objective truth of national culture; they became factors of the "destiny of a people" and irreducible ethnic bond or, in the case of the United States, the product of republican will. Hence the inescapable national classifications for art and literature scholarship. Now that those destinies and bonds have started to unravel, however, the function of English and the responsibility of its practitioners has become a thorny question, and touched off an avalanche of commentary.

4. The role of the nation-state looms so large in Shumway's historical account, however, that he is reluctant to recognize that its time has now passed. Though his narrative ends around midcentury, he closes with the prediction that, "The future of American literature... will continue to serve the interests of the state" (359). This comes after several pages of considering Peter C. Carafiol's cogent critique of fallacious, representative thinking tied to an "American ideal" in much contemporary Americanist scholarship. Shumway not only credits the argument, but he turns it back on Carafiol to even greater effect (351). He goes on, however, to conclude the book by upholding what one might call the "nation-state ideal." Aware of the capaciousness of the American ideal which allows the notion of "America" to accommodate views as divergent as Emerson's and Jane Tompkins's, not to mention Carafiol's - Shumway nevertheless grants that something is there. Indeed, it is something formidable and wily enough to control the direction of literature as an institution for the foreseeable future.

5. On contemporary master's program demographics, see Conrad, Haworth, and Millar 19-21. 
The literature of "institutional studies" goes back at least as far as Richard Ohmann's English in America (1976), which also initiates a major strand in arguments about the role of English. Ohmann replaces the cultural authority of the nation-state with the moral authority of socialist revolution, contending that what ultimately should motivate English is the political emancipation of students and resistance to the capitalist state. By engaging English in a grand narrative of political liberation, Ohmann updated a left discourse of English that would go on to shape the argument of cultural studies - a program that clings to a redemptive or subject-forming role for education, but which redeems students through political insight instead of strictly cultural knowledge. A second major strand in the literature replaces the cultural authority of the nation-state with the institutional authority of the academic profession. Probably most identified with the writings of Stanley Fish, this position abjures a moral or subject-forming role for English and instead recognizes the authority of professional consensus: what makes the study of literature a legitimate enterprise is what makes any enterprise legitimate - the consensus among those who practice it that it is legitimate.

More recently, John Guillory's landmark Cultural Capital (1993) has added an astute sociological dimension to the discussion. Building on the sociological studies of Pierre Bourdieu, Guillory analyzes the knowledge produced by literature departments not as a key to cultural or political truth, nor as merely the product of some detached professional consensus, but as a hallmark of knowledge "capital" that can be translated outside the institution into prestige and financial rewards. The problem of legitimation in the English discipline can be attributed to the rise of the "professional-managerial class" (PMC), which no longer values the cultural capital that the study of literature cultivates - the capital of "the old bourgeoisie." All that those in English can do about this, Guillory argues, is make sure that they provide equal access to the means of cultural capital - i.e., the canon and canonical status - which he suggests would diminish the PMC's power and return the value of English's cultural capital to its earlier levels.

The present study takes as its starting point Bill Readings's remarkable book The University in Ruins (1996), which rejects each of these approaches. Readings recognizes the Marxist program of Ohmann as flawed in the same way as the project of national culture that precedes it: both subject education to grand narratives of emancipation and autonomy that seek to put an end to questions of value and judgment, to finally resolve them. And he recognizes Guillory as sharing this defect too. In renovating the system of cultural capital, Guillory would renovate the regime of national culture and notion of cultural "unity"; he would restore to national culture the authority that the market, in the form of the PMC, has usurped.6

Readings also recognizes that appeals to professional authority permanently bracket questions about value and judgment, silencing them in an insidious way - through the discourse of "excellence." Now ubiquitous in university policy statements and program descriptions, the idea of excellence glibly moots the menacing questions of value and

6. Guillory's conclusion, however, in no way invalidates the incisive arguments that lead up to it. In particular, his discussion of the PMC and the English discipline's reaction to it greatly amplifies Readings's account of the demise of the nation-state, and for that reason will feature prominently in this study. 
purpose across the disciplines because it is an empty criterion, because it diverts the question to a vacant referent. Something is truly excellent only in a certain regard or in the context of specific criteria; but everyone is, naturally, content to be thought of as excellent. Excellence provides the terms for the university's self-critique, but guarantees that genuine critique never takes place. Administrators can appeal to it and mean one thing, while academics mean another, and students still another. As a cause it unites all parties through a mirage of commonality.

Excellence's elasticity has made it the animating principle of the corporate university. The only external constraint on it is the will of the bureaucracy; anything can be excellent - the most virulently radical anti-American, anti-university, anti-bureaucracy theorizing - so long as it poses no obstacle to the functioning of the bigger system. That is why radicalism has proven a healthy draw to universities and no obstacle to remaining in the university. Like technology, which largely creates the conditions for its ascendancy, excellence subscribes to no ideology or ethical framework other than that of the cash-nexus, that of the most efficient input-output ratio, which demands the constant reification of knowledge into quantifiable units. Therefore, while all appearances indicate vibrant academic autonomy on the campus, what the university actually enjoys is financial autonomy - the freedom to fend for itself in the capitalist world-market - to which academic autonomy and ethics must ultimately take a back seat. 7 To Readings, the "contemporary university of excellence" can be properly understood only as an enclosed corporate-bureaucratic system that operates first of all in order to keep operating, without concern for wider social or ideological causes. As such, "it should no longer be thought of as a tool that the left will be able to use for other purposes than those of the capitalist state" (41).

This makes for a sweeping and uncompromising argument, but it is one which strikes me as extraordinarily honest and compelling. My study proposes to narrow its scope somewhat by analyzing and understanding the West Virginia University English department and the English discipline in the United States more generally in light of The University in Ruins, as a case study or clarifying instance of Readings's insights. It will begin with a history of the university highlighting the rationales and arguments that have shaped it, and sketching a genealogy of contemporary claims about the university's mission and social relevance. Here I will trace WVU's progress from a university (or more

7. Not surprisingly, the mercantilization of research is more advanced, and audacious, in the sciences, particularly in research with highly lucrative applications for the pharmacological industry. According to an August 2000 Washington Post article, biomedical researchers and their universities not only routinely benefit financially from their own research through equity ownership, but they have been known, on several occasions, to actively initiate and sponsor their own research projects as majority owners and founders of private biomedical companies. In one of the most notorious cases, University of Pennsylvania researcher James M. Wilson carried out human gene therapy studies in the fall of 1999 that resulted in the death of an 18-year-old volunteer patient, Jesse Gelsinger. An independent review of the incident revealed that the research was funded by Genovo Inc., a company Wilson helped found and largely owned, and which had given the university an equity stake before the project began - relationships which the outside investigators of Gelsinger's death concluded were "ill advised" (O'Harrow A01). 
properly a college) organized around the idea of national culture to a "university of excellence," beginning with the missionary presidency of Alexander Martin and leading up through the zero hour of the Vietnam-era protests, when students confronted the reality of "mass education." Next I will examine the department's adjustment to the regime of excellence, focusing on the institutional ascent of composition and literary "theory" as significant chapters. The study will close with a discussion of Readings's views on how the university of excellence might function as a "ruined" institution and remain above all a space for thinking. 


\section{Chapter 2: The University}

\section{From soul to state}

The terms of the Morrill Act of 1862 — which provided the capital to found WVU and other land-grant universities - laid out a practical, trades-focused mission for state universities by stipulating only that agricultural, mechanical, and military instruction be offered. But what was not stipulated left enough room for far more ambitious curricula. In his history of higher education, The Emergence of the American University (1970), Laurence R. Veysey describes how idealistic college presidents often insinuated grander goals. The legislation suggested something on the order of "pretentious trade schools," Veysey writes. "[B]ut academic reformers with loftier intentions often secured control of them [the colleges] in their infancy and made them entering wedges for their own plans" (15). Hence WVU's first president, Alexander Martin, envisions the day when West Virginia's land-grant college "shall be to her what Yale is to Connecticut, Harvard to Massachusetts... or Oxford to old England - her brightest ornament and crowning glory" (19). Martin argues at length in his inaugural address against a narrow definition of "West Virginia Agricultural College" (as it was originally known) as primarily a trade school. Rather, the professional competencies mandated by the Morrill Act would depend fundamentally on the lessons of "general" education, on the development of "a well-balanced and symmetrical character":

The work of the College is not so much special, as general - seeking to prepare men to look within and see how fearfully and wonderfully they are made, and with open vision on God's universe without... in short to educate men, as men, and not as machines. Neither this nor any other College propose to finish either a practical or professional Education, but by careful discipline and earnest cultivation, to awake, develop and strengthen every power in full and fair proportion, and lay the foundation of a character fitted to appear with capacity, and disposition for good in any sphere, relation or occupation. (22)

"General" here implies a totalizing principle of knowledge synonymous with religious and philosophical enlightenment. If "special" study is special to a certain profession or discipline, then general study takes in all specialties and disciplines; it integrates them the way God integrates the particularities of the universe.

This sentiment aligns Martin philosophically with the medieval church-centered university model, along the lines of Oxford. And yet, in admitting a role for professional training and direct university service to the state, Martin also embraces the tertiaryeducation reformers who were at this time starting to emulate the modern German research university, which supplants religious rationales with more broadly scientific and social ones. $\underline{\mathbf{8}}$ On the face of it, Martin is an advocate for Christian and "Western," not national, culture. But in meticulously working out a relation between, on the one hand,

8. See Veysey's introduction on "The Rise of Academic Reform" (1-18) and the later section "The Lure of the German University" (125-133). 
practical training that is of immediate and special use to the state (i.e., farming and soldiering), and, on the other hand, general or moral education, he in effect locates a common denominator in something more specific than godhead. God integrates the particularities and disciplines, but something else does too: the totality of the state, the idea of national culture. The universe that "general education" generalizes from is emphatically not the universe or even "the West," but the nation-state.

Historically, this has been the "classical" deployment of the classics in nationalist projects, a point that Guillory makes persuasively. The religious and western philosophical traditions have proved better equipped conceptually than national literatures for demonstrating a grand, uninterrupted tradition of humanist learning and thought from ancient times to the present. But, Guillory argues, "the fact remains that this continuity was always the historical support for nationalist agendas. The schools in the early modern nation-states provided an instrument by means of which the state could dissolve the residually feudal bonds of local sovereignty and reattach personal loyalty to itself" (42). In Martin's modern America, these prenational traditions similarly work to dissolve the claims of class consciousness and residual ethnic identifications into a "general" culture which is actually national culture. In one fascinating, sweeping passage, Martin situates the college as the telos of a world-historical project of American civilization that appropriately springs from European civilization and at the same time surpasses it:

One century ago and this beautiful valley, now so richly embellished by the enterprise of man, with pastures, and orchards, and fields, and dwellings of neatness and comfort, was a vast, uncultivated wilderness. ... What a change in that time have the wondrous expansion and boundless activities of free institutions produced? ... [O]n this continent [they have] aggregated an Empire, compared with which European kingdoms are dwarfed into provinces. Who shall compare the dimensions of the finished structure, or calculate our unparalleled and irresistible progress in the ages and centuries to come.... Ye are blind, and cannot discern the signs of the times, or read either the past or the future as you should, who say West Virginia should not then have a College equal to the best of those now in our land. (20-1)

The italics here are mine, and mean to underscore the coded nationalistic contrast of American civilization as "free institutions" against European civilization as a domain of royalist tyrants. In this way, Martin incorporates the study of practical disciplines like agriculture and soldiering into the moral and political project of nation-building.

Nowhere is it clearer that the nation-state takes primacy over an abiding humanism or Christianity in Martin's model than in the fate of those students desirous of strictly vocational training. Martin declares: "Man should be educated not because he must study or work, but because he is a man, allied to God and destined for immortality" (23). But in the very next breath he allows that the noble path of general education is not for every man - for instance, those with "inadequate preparation, insufficient health, or other disability" (24). By dint of the Morrill Act, not to mention the economic imperatives of industrialization and postwar reconstruction, the university must accommodate these stu- 
dents too, rather than correct their priorities; service to the state thereby trumps service to the soul.

At the same time, it would be a mistake to interpret "service to the state" in Martin as a mechanical response to labor demand. In conceding the necessity of offering a "partial Course" of specialized agricultural training, Martin refuses to concede the purely economic necessity of professional and specialized instruction to the state as patron. Instead, he revalues farming as a noble legacy of classical Western culture, which, to reiterate, issues directly into American national culture. The agricultural science curriculum promotes "an employment which Cicero declares to be most worthy of a freeman":

in which Cato and Cincinnatus delighted - which Virgil celebrates in his Georgics, and Horace sings in connection with his Sabine farm, and which the farmers of Mt. Vernon, Clermont, Marshfield, and Ashland, as well as many of the noblest of our world, from Adam down to the present, have illustrated and adorned. (24)

Farming thereby overcomes simple, subnational economic utility. Becoming trained farmers, students would simultaneously become heirs and upholders of Western tradition and values. They serve the state by helping enrich and perpetuate its culture. When he refers to "general education," then, Martin actually means "cultural education" in the sense of national culture.

So much for agricultural studies; as a modern university discipline, it is redeemed by its classical heritage. But Martin foresees the university eventually educating men in "all the Professions and Pursuits of life" (9). How will it ensure that such future professional studies will, like agriculture, transcend simple economic utility? This is not a question that he dwells on, but the answer appears to lie in the curious circumstance whereby agriculture students affirm and promote national culture without realizing it, without recourse to formally studying the tenets of that tradition. A kind of educational and cultural symbiosis binds the college's pragmatic Agricultural Department to its higher Collegiate and Scientific departments. Presumably, it would bind future professional studies to a higher, cultural mission as well.

Here Martin's debt to the modern German research university, emerging at this point as the model for land-grants, becomes apparent. Specifically, it is the seminal influence of Kant's discussion of the university in The Conflict of the Faculties (1798) that informs this aspect of Martin's framework. In Kant's university formulation, the general, or philosophical, faculty regulates all the other, more practical faculties - not, however, through any political or institutional dominance. In fact, it is the practical faculties, those that serve the government more immediately — specifically, the law, medicine, and theological departments - that seem to hold the cards politically, thus Kant terms them the "higher" faculties. But philosophy, the heart of the "lower" faculties, has the last word through its commitment to a transhistorical truth, the influence of which filters down into the activities of the more "useful" departments, ultimately guiding their course:

[The philosophy department's] function in relation to the three higher faculties is to control them and, in this way, be useful to them, since truth (the essential and 
first condition of learning in general) is the main thing, whereas the utility the higher faculties promise the government is of secondary importance. (45)

As a result of philosophy's speculative investigations into what is true, "the higher faculties (themselves better instructed) will lead these [government] officials more and more onto the way of truth" (47). The different faculties will always engender conflict. The only condition Kant requires to keep the conflicts "legal" is that the lower faculties be left free to evaluate everything according to the laws of reason. That way, the lower faculties' investigations would remain more purely rational and more inclined to arrive at the truth.

It was left to Kant's intellectual heirs, the German Idealists like Wilhlem von Humboldt who would found the University of Berlin in 1810, to effect a crucial innovation the replacement of reason, which acts as the guiding principle in the Kantian university, with the idea of culture. The university of culture regulates itself by the attempt to reconcile reason to culture and tradition, not culture and tradition to reason. Taken to its logical end, Kant's trust in reason would destroy tradition; Humboldt, on the other hand, was concerned to preserve tradition by theorizing a rational, organic basis for it. The nation, for example, would be redeemed as a natural collectivity, with a basis in ethnicity and rational self-consciousness. And the university would function as the institution for instilling such consciousness even as it participated in the hermeneutics necessary to reveal it - a dual responsibility that forms the yin-yang of teaching and research. The conceptual shift from a Kantian to culturalist outlook can be seen in the replacement of philosophy with literary studies as the university's central discipline. It is literature, and not philosophy, that unites people into a nation. 9

The West Virginia Agricultural College would have its lower and higher faculties as well - a balance of practical and impractical that more than anything else distinguished it from the ecclesiastical "old college" model of Oxford and Harvard at this time. The higher faculties would always serve the government's immediate, transitory needs, e.g., agricultural production. The lower, alternately, would concern itself with deeper, immutable things, and in doing so lead the other faculties and government "more and more

9. My account of the University of Berlin's founding draws heavily from Readings's, in his chapter "The University and the Idea of Culture" (62-9). It is rather reflective of this history and the contemporary trends I have been discussing that German universities have long resisted professionalist education, and suffered greatly for it. A February 2001 Wall Street Journal article finds evidence of a general decline in German higher education; spurning private spending and the "American approach," the universities have grown seriously underfunded and watched as professors and students go abroad in search of better conditions. In the past year, however, professionalist reforms have begun to gather steam in the Federal Education Ministry and on several university campuses, one of which is Humboldt's University of Berlin itself. Since renamed Humboldt University, it has become the first German university to employ full-time administrators and recently adopted a series of changes introduced by President Juergen Mlynek, including curricular modernizations, the offering of grants for research in the sciences, and the training of staff in "customer service." "The idea of the student as a customer is a bit contradictory to Wilhelm von Humboldt's idea of the university that offers a broad, general education," Mlynek acknowledges. "But today, you have to train people for the labor market" (Rohwedder and Wessel A1). 
onto the way of the truth." It would not be housed exclusively in the philosophy department, but rather in the "Collegiate department," Martin's seat of general education. Like Kant's lower faculty, it would exercise regulatory and virtual control over all the disciplines.

\section{From state to system}

It was not until ninety-seven years later, in 1964, that a more formal integration of university activities would become necessary, in the introduction of a mandatory universitywide "core" curriculum - consisting of English composition, remedial math, and selections from three clusters of humanities courses (Core Curriculum Committee 3). The core proponents rehearsed essentially the exact arguments Martin had made, posing the temporal pressure to specialize collegiate studies against the moral and cultural need to integrate them. The religious imagery was gone, rearticulated as a commitment to "liberal education" and "common cultural heritage."10 But the big change was that something had happened, after a century of steady university expansion, to wipe out the virtual authority that general education had so long enjoyed, at least in theory. The lower faculty was no longer influencing the higher faculties with an invisible hand. And the solution seemed obvious: make official what had been virtual, institute a required general-education curricular component across the university.

Of course, the very need to legislate the role of cultural education in this way signaled not only the end of its primacy but the end of its legitimacy as well. Instituting the core curriculum amounted to a rearguard action against encroaching professionalization and student diversity, both of which wreck the idea of unified culture. On the one hand, the emergence of a professional-managerial class over the course of the sixties and seventies marked the beginning of the end of the regime of national culture. A class with surging power, the PMC valued less and less the distinction that came with cultural education because such distinction no longer determined social and financial success. On the other hand, the increase in enrollment by women, blacks, and "lower" classes $\underline{\mathbf{1 1}}$ began to traumatize on a classroom level universities' exclusionary definition of culture.

Complaints arose immediately, from all quarters, and all underscoring the historical lateness of such a program. From its natural enemies, the professional schools like Engineering and Forestry, came the protest that their standards of professional competence would be impossible to meet (Core Curriculum Committee 2). And from the core's most enthusiastic advocates issued the criticism that no one was taking the idea of culture seri-

10. The official "goals of a core curriculum," as articulated by the Committee on Student Instruction, a University Senate panel charged with reviewing it in 1970: "[T]he general introduction to and appreciation of the elements of our common cultural heritage, the inculcation of certain common skills, and the formation of the individual with values, attitudes, tastes and traits associated with the educated man" (1).

11. The percentage of male students enrolled at WVU fell from 62.8 in 1971-72, the first year such statistics were compiled, to 53.5 in 1995-96, the latest results available. The percentage of white students has fallen from 96.3 in 83.4 in 1983-84 (also the first year for such data) to 89.0 in 1995-96 (West Virginia University 1997). 
ously. English Professor John Stasny, chairman of the University Senate panel convened in 1967 and charged with reviewing the core system, blamed the university's professionalist outlook with undermining the core and the very idea of liberal education:

The Core Curriculum is caught (as is undergraduate liberal education generally) in the drive toward specialization. (Lip service is paid to its aims, but sacrifices entailed in its implementation are too often and too easily altogether refused or, with subversive consequences, begrudgingly and mechanically fulfilled.) Without any evidently very high administration priority, with less than vigorous faculty support, students docilely but unenthusiastically approach Core as a distraction from their primary educational concerns and as a series — to be endured with resignation - of factitious hurdles, a certain number of which have to be surmounted on the path to a degree. (1)

In its tidy equations of credit hours and humanities-clusters, the core more or less announced its endorsement of the accounting mentality of professionalism (and, of course, prefigures excellence). This way, it achieved a compromise between professionalism and culture at no great cost to professionalism - twelve or so credit hours - but at tremendous cost to culture, in effect crudely commodifying its grand mission of forging student subjectivities. Naturally, the professional schools considered even twelve hours too great a compromise. In any event, no one thought general-cum-cultural education was properly valued; and everyone agreed that it no longer controlled the university, it no longer held the center.

Stasny's remarks indicate the disaffection that students also felt toward cultural education as the university conceived of it. The very fact that their point of view entered into the argument signals perhaps the most momentous departure from Martin's university, in which students were passive entities to be shaped by the influence of culture, not consulted or appealed to on their own terms. In a few years' time, they would break completely and dramatically with Martin's narrative, asserting themselves as legitimate opponents of the university on the issue of the Vietnam War. The war protests represent the tipping point for the transformations in national and university politics central to this thesis, the point at which popular assumptions about the university's historical mission to inculcate culture finally collapsed. So an examination of the moment of the protests and their aftermath will close this section.

This period is often remembered by left and right alike as decisive in delineating contemporary political alignments, on campus and off. But what seems most extraordinary about the student protests is the way in which they dispensed with the program of conventional, i.e., representative, politics. In my understanding, the political issue per se - the rightness of the war - took a secondary role to the fact of the protests as a rupture in the narrative that says the university benevolently "completes" students as cultured national subjects. By opposing the university, students decisively repudiated the university's parental authority over them. In doing so, they overrode the question of how best to represent the populace (the question of the rightness of the war, in this case) by questioning the very notion of political representation; they challenged the idea that a legitimate, de- 
mocratic state apparatus like the university could have the authority to arbitrate what it is to be a person. On the contrary, the university's authority now extended just far enough to credentialize students professionally.

It might be useful at this point to review the events in question. In October 1969, students on the Morgantown campus staged several days of demonstrations in conjunction with the Moratorium observance. The following May, the shootings at Kent State generated new demonstrations. This time, student groups broke into the ROTC center in Woodburn Hall and ripped up manuals. Then they moved to Stewart Hall, demanding that President James Harlow condemn the shootings in Ohio and the Cambodian invasion. Denied a meeting with Harlow, more than 3,000 protestors massed on University Avenue until Gov. Arch Moore called in state troopers, who sprayed tear gas and eventually negotiated a peaceful end.

In divorcing the protests from left-right political discourse, the first thing to note is the essentially symbolic role that the war played in them. Though the unrest arose ostensibly in response to the war, the changes instituted in the wake of it had almost nothing to do with the war per se: no anti-war or anti-draft policies were implemented, nor were anti-imperialist-themed courses formally introduced, etc. The second thing to note is the smallish scale of the action, relative to other campuses nationwide and relative to the impact they would have on university policy. By this I mean that the protests themselves would take on a highly symbolic quality too; though shortlived and largely nonviolent, they helped set off a series of long-term changes that would touch on nearly every practical aspect of student life.

The war's symbolic quality can be demonstrated more clearly in the example of a smaller West Virginia college. On the same day of the biggest WVU protests, May 8, 1970, a day of war protests on other campuses in the state and across the country, about 75 students at Alderson-Broaddus College in Philippi ended a daylong occupation of the administration building. They were not, however, protesting the war but rather demanding that the Baptist-run college reconsider their proposal for the creation of a blackstudies department, a demand which faculty members and administrators eventually granted (Ammerman 8A). The upshot is not that the A-B protestors were seizing, in an opportunistic way, on a general spirit of campus revolt, nor that such simultaneous protests were simply coincidental. Rather, the unrest boiling over at each college and university involved issues that extended beyond the war itself, but for which the war - as an instance of autocratic brutality - provided the most galvanizing and immediate rallying point.

At WVU, the protesting students' ostensible demand, that Harlow merely issue a statement condemning the invasion of Cambodia, could not have been less substantive or more symbolic (especially in view of the fact that Harlow's brother was at the time a Nixon cabinet member). The demand was in a sense beside the point. The point, as in other campus protests, was never coherently articulated or comprehended. But it had something to do with disrupting the institutional structure that hitherto had framed all debates. It had to do with reconfiguring the place of students as developing "symmetrical characters" or mute receptacles, and the place of the university as a foundry of unified 
national culture. That is why the major campus reforms in the end centered on changes in student life, on changes aimed at elevating students' status vis à vis the university.

In their account of the events at WVU, university historians William T. Doherty Jr. and Festus P. Summers correctly interpret the protests and subsequent reforms as indicative of the emergence of "a new kind of student," distinguished by "liberated thinking and their push for more individual freedom" (320-1). The university would, for instance, relax regulations concerning sexual practices and alcohol consumption. A new law allowed the university to hire attorneys to represent students in extra-university cases. All departments developed student course-evaluation protocols. More students were invited to participate indirectly in university governance. And a curriculum overhaul followed. Courses on black history and literature and women's studies were added as were variations on the grading system (323-4). These changes signal a wholesale reevaluation of the student's status on campus. They reflected the fact that the terms of students' contract with the university, a contract historically conceived as constituting an in loco parentis bond, had changed radically, had broken down.

Acting in this new status, Mike Connor, Student Administration president for academic year 1972-73, petitioned for direct student representation on the University Senate, arguing that "a program of greatly expanded participation and shared authority is a forward step commensurate with the new maturity students have asserted and wish to employ" (7). Connor's campaign is especially instructive for its acute attention, unshared by many university officials, to the new institutional reality of "mass education":

When we acknowledge the students' membership in the University by asking him [sic ] to directly share the responsibility for governing it, we express the hope that such participation will invigorate the intellectual fellowship that has been lost in the process of maintaining an efficient system of mass education. (University Senate Minutes Dec. 11, 1972 388)

At the moment of the protests, students like Connor had begun to perceive that their relation to the university was essentially bureaucratic, that they acted in effect as consumers. $\underline{\mathbf{1 2}}$ The rhetoric of child-and-parent and subject-in-formation therefore had unraveled, and there was no longer any reason to defer full rights of citizenship and adulthood. In order to restore genuine intellectual exchanges, Connor viewed it as imperative that the university formally recognize students as adults, that it officially repeal the ruse of education as subject-formation. Similarly, in Doherty and Summers, administrators sympathetic to the uprisings note that contemporary students had grown more "human." Just after the protests, university housing director Robert Robards, who is "certain a new student had emerged," could declare that, "Within the last five years, the students have become human beings rather than just numbers in the administrators' eyes" (321).

Far from initiating the era of student activism and high-mindedness that Connor en-

12. A 1968 review of the core curriculum mentions that one unidentified core course, held offcampus at the Metropolitan Theater and staffed by only one instructor, had an enrollment of 800 . A music course taught in the Music School Auditorium enrolled 587 (University Senate Agenda April 8, 1968 2-3). 
visioned, however, the protests and reforms instead marked the onset of decades of student apathy. As it turned out, the immediate sequel to the demonstrations proved to be egregious campus vandalism that persisted much longer, throughout the decade. Reports of dormitory-trashing left state citizens and state officials outraged.13 But it was the outrage of two newly divorced parents "perplexed" at the sudden tantrums of their child. The way to interpret this second wave of student behavior, so out of joint with the conscientiousness of the reformists, is as the normalization of the same disaffection that had led to the reforms - the disaffection with the collapse of the university's marriage with the state. It was under the false pretense of the narrative of cultural education, after all, that students were (and still are) required to reside in the controlled environment of the dormitories in the first place, for the benefit of the full "university experience."

The difference between these two reactions, protest and apathy, deserves further analysis. The protests occurred as an attempt by the student vanguard to reimagine the place of students within a postmodern university - no longer as subjects-in-formation or even as bearers of a "common culture," but rather as something unclear and unprecedented, as people engaged in study, now on an equal footing with professors and administrators, inferior only in having mastered their study-topics less completely than their instructors (who, after all, would never master those topics completely themselves). The apathy that followed, and which persists, was simply the inevitable response of the undergraduate students at large to their place in the university that emerged, the university that situated them as customers. By "apathy" I do not mean anything so superficial as the absence of overt political activism, but rather the pervasive attitude among students that they are merely "driving through" — paying their money, sitting through classes, getting credentialized for a good job. That a few students today continue to view their education at least potentially as something more attests to the residual but waning power of the old model, and to their remarkable desire for college to be more without being superfluous.

13. Reporting on the dormitory-trashing of 1975, The Chronicle of Higher Education put costs at $\$ 50,000$ and detailed damages like yanked-out sinks and toilets, torched furniture, and broken windows (Doherty and Summers 322). 


\section{Chapter 3: The Department}

\section{'On such questions, we will not enter'}

On the question of whether the study of science is more important than that of languages, we will not enter. As well might we discuss which is more necessary to a man, his hands or his feet, his head or his heart, or whether he could better subsist on a purely vegetable or a purely animal diet. — Alexander Martin, "Inaugural Address"

In Martin's university, the study of language and literature maintained literally unquestioned status vis à vis the university and society. It acted as the guardian of those texts that served two functions vital to creating cultured national subjects: illuminating preeminent cultural values and modeling the language for communication within the culture. As moral guide, the study of language "opens up treasures of instruction." As a model of language, "it furnishes the key to the nomenclature of nearly every other science" and "gives range, accuracy, and precision to our thoughts, and a rich and copious diction for their expression." If the utility of agricultural science seemed self-evident, the necessity of literary instruction was no less so. "[I]n our land and age to call any man educated who has not a respectable knowledge of both science and literature... is simply absurd" (25).

In principle, the core curriculum aimed to consolidate the authority of this role for English through its inclusion of literature and composition courses. But in practice it did the opposite by construing culture performatively, hastening the social marginalization of English and the other humanities disciplines. In effect, the university acknowledged that Martin's program of cultural education could not withstand legal conflicts with the higher, more practical faculties; the idea of culture could not survive on its own in the "real world" even though it pretended to issue from reality. Kant never lost confidence in the power of philosophy and reason to redeem themselves and convince others; all he required, to reiterate, is that one faculty remain free to judge everything according to reason. Martin had as much trust in culture, as evidenced in his advocacy of a "partial Course" above. But at the time of instituting the core curriculum, all such faith in the power of culture to evidence its own soundness had evaporated. So the university propped up the idea of culture by requiring cultural education of everyone; it forced culture on all students, blatantly exposing the performativity of the cultural mission. Stasny's criticism, that students as well as teachers were simply jumping through core hoops, reflects the fact that both parties clearly recognized cultural education for what it had been all along: a performance, not at all a revelation or destiny or fulfillment of national birthright.

The core curriculum, then, marked the last stand of legitimacy for the idea of national culture. As such, it also initiates the regime of excellence (though the widespread appeals to "excellence" specifically would not come until the mid-eighties and nine- 
ties $\underline{14})$. As the core curriculum demonstrates, the hollowness of the cultural idea proved no obstacle to employing it as if it were not hollow, which is the pattern with excellence; it allows the university to continue to function as if it served Martin's cultural mission, the production of unified cultural subjects, while obeying instead a primarily professionalist and bureaucratic imperative. In the department, the reign of excellence was first the occasion for great gnashing of teeth by the older faculty - a painful recognition of the marginal role that their purely literary approach to English would take in a society no longer seen as perfectly integrated by culture. Their anxiety only deepened as two new forces within the department began to gain institutional clout: composition and literary "theory." The composition component escaped the marginality of traditional literary studies by bringing a sense of bureaucratic order to English and by teaching marketable skills. Theory similarly accommodated bureaucratic administration and added an air of scientificity. But it also won over the department because it could retrofit Martin's cultural mission to excellence, shoring up the crumbling facade of disciplinary integrity and social relevance.

\section{The professionalist turn}

It may seem contradictory to speak of encroaching professionalism in what is obviously and necessarily a profession. But just as the level of nationalism can subside in a nation - for instance, in the face of cartelization on a global scale — so, for precisely this reason, has the discourse of professionalism grown overwhelmingly more influential in the profession of academic English. In other words, professionalism names an ideology of being in the professions - or even a "culture," as Burton Bledstein describes it in his

14. Nevertheless, symptomatic references to excellence do begin to emerge at WVU in the midseventies, and then accelerate rapidly (culminating in the development of a Center for Writing Excellence currently under way). For example in a 1974 review of the English department (to be discussed in greater detail subsequently), which surveyed faculty members for their opinions on a variety of department activities, five participants "responded to the effect that the teaching was 'excellent' and all the programs were of the highest quality" (Herrera 5). Elsewhere the report's authors appeal to "[e]xcellent instruction in writing" (3) as a laudable goal.

Eight years later, a followup department review (also to be considered presently) would intensify the rhetoric considerably. This report's concluding section, a 30-page analysis by University of Kentucky English department chair Robert Hemenway, invokes excellence every other

page, on average. Furthermore, Hemenway references excellence in highly symptomatic ways, as a specific standard of assessment. For instance, he recommends that "promotions and tenure... should be a reward for excellence in both scholarship and teaching," and that "the full and associate professor rank should demonstrate continued excellence in both scholarship and teaching" (102). Course-release, he argues later, should be "a direct reward for publication of excellence" (122), as should a variety of other privileges: "Those tenured faculty who wish to be known as teachers and scholars could be rewarded for excellence with the privileges of rank - graduate students, upper division courses, travel money, promotion, lower course loads, etc." (126). But Hemenway's non-specific references to excellence are probably even more significant, as they imply a more integral and ideological function for the concept. "The English faculty must collectively pursue excellence as scholars and teachers" (128), he concludes his comments. 
analysis The Culture of Professionalism (1976). And as with the discourse of "globalization," which portrays the globalized political economy as inevitable and totalizing, $\underline{\mathbf{1 5}}$ the apologetics of university professionalism also would naturalize professional arrangements, ultimately promoting tighter integration of the university into the worldmarket.

To "be professional," after all, is to act in the interests of a certain segment of the labor market. The traditional defense of professionalism, as Magali Scarfatti-Larson shows in her landmark sociological study of professional life, The Rise of Professionalism (1977), has camouflaged normal capitalist relations within the professions by positing professional interests as "humanitarian." And while contemporary advocates of professionalism make a different case, it is one that similarly neutralizes the impact of the market. The contemporary argument poses professional arrangements and interests as univer$s a l$, as encompassing every possible relation and interest that those in the university may be called upon to negotiate; and if every action necessarily serves professionalism (thus answering to the market), then it makes no sense to think of academic work as being potentially influenced or not influenced by capitalist relations, as being more or less professionalist. As in the traditional argument, the question of the role of capitalist relations disappears.

Hence Stanley Fish, whose cogent elaborations of professionalism place him at the forefront of its contemporary defenders, has described "anti-professionalism" as an impossible proposition - a point of view that embraces empty essentialist causes like transcendent truth and political disinterestedness, thereby surrendering institutional awareness. Thus anti-professionalism "is indefensible no matter what forms it takes":

[A] practice cannot (or should not) be criticized because it is professional, because it is underwritten by institutionally defined goals and engaged in for institution-specific reasons; since here are no goals and reasons that are not institutional, that do not follow from the already-in-place assumptions, stipulated definitions, and categories of understanding of a socially organized activity, it makes no sense to fault someone for acting in the only way one can possibly act. (242-3)

Fish's arguments, here and throughout his other discussions of professionalism, involve an unexplained conflation of the "institutional" with the "professional," a melding that implies an obligatory capitalist context for all socially organized activity. It is one thing to assert that institutions and other social organizations (including Fish's now familiar "interpretative communities") will always mediate academic goals and practices though even that appears to be a less agreeable state of affairs than Fish seems willing to

15. Jan Currie, co-editor of a recent volume titled Universities and Globalization (1998), borrows Michel Foucault's notion of a "regime of truth" in characterizing the contemporary ideology of globalization. "[G]lobalization is presented as an all-encompassing and irresistible idea," she writes. "When most government agencies and politicians are speaking with one voice that suggests globalization practices are the only answer for all nations, it is difficult for other voices to be heard. ... These ideas have become almost like common sense and are not easily challenged" (10). 
admit.16 But it hardly follows that such goals and practices must therefore always accord perfectly with those of particular professions — which, as Larson demonstrates, exist in order to monopolize various sectors of the labor market.17 Once unearthed, the subtext of Fish's arguments evokes Marx's depictions of capitalism in its most advanced and grotesque stages, in which market relations suffuse all relations. I hasten to add that institutional arrangements in universities need not succumb so completely to capitalist relations in order for professionalism to seriously compromise academic ethics and vitality. An insidious legacy of professional power has been to preserve, for much longer than can be justified, the bureaucratic university hierarchies and disciplinary boundaries on which professional authority and mastery are ultimately based. To put it another way, my antiprofessionalist critique is not opposed to any institutional structures guiding academic practices - which is Fish's rather limited conception of anti-professionalism. Rather my critique opposes the same ones, enshrined and perpetuated in service to professional interests and for that reason inseparable from the process of marketization.

For instance, even when the criticism of disciplinary boundaries has gathered steam, as with the transdisciplinary reorganizations advocated by proponents of cultural studies, it has invariably been appropriated and domesticated by the reigning academic bureaucracy, as Readings argues in his acute analysis of the institutional rise of cultural studies. He points out that, "the cry of Cultural Studies that the University must be left behind has proved a particularly fruitful way of staying in the University" (91). This should not be taken as an indictment of the motives of those who practice cultural studies but rather as an evidence that the program of cultural studies, for all its political outspokenness, has practically nothing to say about current professional arrangements. Though it denies national culture, or "high" culture, the authority and redemptive capability that those like Martin had ascribed to it, cultural studies has no problem proposing that the study of a

16. Samuel Weber, in Institution and Interpretation (1987), remarks that the solution Fish proposes to the problems in literary studies becomes on closer inspection a manifestation of the problem itself:

[T] he "institution" or "community of interpretation" to which Fish so strongly appeals is no longer simply a unified, undivided community, "within" which the diversity of individual interpretations take (their) place. Rather, what bothers critics and what renders literary studies often an inhospitable place to live and work, is the fact that there is no longer a generally held "set of institutional assumptions," since all such sets have themselves become "the objects of dispute" (35).

17. Larson writes that, a "tendency to monopoly by elimination of competing 'products' was inherent" in the initial development of professional services. "[F]or if other standardsof evaluation were allowed to prevail," she continues,

the preference of the public could not easily be reclaimed away from older "consumer loyalties." Professional entrepreneurs, not unlike their counterparts in industry, were therefore bound to solicit state protection and state-enforced penalties against unlicensed competitors - that is to say, those producers of services whose training and entry into the market they had not controlled. (14) 
non-exclusionary "culture" can play a redemptive role and restore a social mission and galvanizing purpose to the university. Its internal inconsistencies aside, $\underline{\mathbf{1 8}}$ this model perpetuates the traditional quasi-priestly authority of professors (as masters who lead students to full personhood) and the legitimacy of current professional arrangements. The musicians keep playing even though the score has ended. In Readings's words, cultural studies "preserves the structure of the literary argument, while recognizing that literature can no longer work.

Cultural Studies does not propose culture as a regulatory ideal for research and teaching, so much as seek to preserve the structure of an argument for redemption through culture, while recognizing the inability of culture to function any longer as such an idea. (17)

Professional power in the university has assimilated other, less militant transdisciplinary experiments, most notably American studies, in similar fashion. In his discussion of American studies, Shumway points out that, though it constituted a new academic field when it emerged in the thirties and forties, American studies never succeeded in raising new disciplinary issues, and instead merely added to the same kind of work that was being done in literature departments. "What distinguished work in American Studies [from that of other academic departments] was not its method or theory but the texts on which it worked," he writes. Thus American studies "continued to assume the general historical relationships that had always been assumed by literary historians" (217). Shumway blames this missed opportunity on the entrenched disciplinary structure of English departments (the birthplace of American studies) as well as on the larger American university structure, both of which bend without breaking: they "welcome innovations" but "have tended to so isolate them that their effects on disciplinary knowledge have largely been nullified" (217-8). In making a similar argument (one cited by Shumway), Gerald Graff in Professing Literature (1987) has lamented the ineffectiveness of a series of promising postwar disciplinary experiments, including the University of Chicago's Committee on Social Thought, Stanford's Modern Thought Program, and the History of Consciousness Program at the University of California at Santa Cruz, in addition to American studies (225). Both Graff and Shumway, however, go on to suggest that the tenacity of disciplinary arrangements derives from the persistence of New Critics and a tradition of anti-historicism as well as more generally from an enduring conservative ideology (alloyed with nationalism, in Shumway's account). This flies in the face of Professing Literature's own central thesis, that ideology and critical orientations have not remained static in English departments but rather aroused almost constant conflict. $\underline{\mathbf{1 9}}$ Professional

18. An unlimited nonexclusionary category like "culture," as defined by cultural studies, cannot logically function as a purpose; on the contrary, in its amorphousness, it resists any kind of unifying action: "If culture is everything," Readings argues, "then the invocation of culture cannot have redemptive force, cannot lend meaning (unity and direction) to symbolic life" (99).

19. Graff writes: "As I have told it, the story of academic literary studies in America is a tale not of triumphant humanism, nationalism, or any single professional model, but of a series of conflicts that have tended to be masked by their very failure to find visible institutional expression" (14). 
arrangements, on the other hand, have always authorized disciplinary arrangements, and have always had good reason to resist meaningful disciplinary shakeups.

The immunity from questioning that professional frameworks in the university continue to enjoy is all the more surprising given that professionalism has been richly theorized by others, most notably sociologists. The classic account of professionalism derives from Max Weber's historical progression from charismatic social structures to bureaucratic ones, a transformation intimately related to capitalism's supplanting of feudalistic economic arrangements. Larson expands greatly on Weber by linking the growth and power of the modern professions to the late-nineteenth century expansion of monopolized capitalism and the integration of science and technology into production and management. She interprets developments like these as instrumental in effecting a dominantideological shift, which largely created the professions and continues to justify their social and economic power today. Bledstein corroborates Larson's account in describing the phenomenon of professionalism as an expansive and saturating "culture": "Within carefully established spaces, rituals and ceremonies began to dominate human relationships and to consolidate the emerging culture of professionalism" (95).

If professionalism can be called a culture, then the professional would have to be its hero. Larson details how the professions refashioned the individual autonomy and Weberian "charisma" of the individual worker - the pre-industrial forerunner to the professional - into the contingent, bureaucratized "professional autonomy" of the "expert." She writes:

Economic growth and productivity - due in large part to applied science - began to be felt at the level of the average standard of living; in this manner, they gave concrete support to the decisive affirmation of science as the predominant and undisputable system of cognitive and ideological validation. Expressed in the emergence of scientific management ideologies and in the notion of a transpolitical state, the shift in dominant ideology legitimized the status of the expert and exalted his role. (200)

Here science functions "as a method and as a world view, more than as a body of knowledge" and authorizes "scientifically oriented experts who act in the bureaucratized institutions of the new social order" (Larson 137). The professions' basis in "science" implied total independence from market relations (which is why students never tip their teachers) and therefore generally shielded the professional from ethical questions, certainly those relating to financial self-interest. But, as Bledstein emphasizes, "science" as a source of professional authority and ethical autonomy not only transcended the market, it also transcended every other realm of self-interest - "the favoritism of politics, the corruption of personality, and the exclusiveness of partisanship" (90). The professionals - and by extension their hierarchies of rank and privilege, the definitions of their fields of competence - would stand beyond reproach.

What is most noteworthy about the professionalist ideology is its lack of ideology, as it is conventionally understood: professionalism nullifies the domains of the market, culture, politics, and subjectivity, thus its supporting role in the "emergence of the transpoli- 
tical state." Professionalism does not submit questions of value or subjectivity to a presumably constative analysis (a fact that Fish, for one, constantly celebrates), as would, say, socialism or Christianity; it refuses to concern itself with the interpretation or reinterpretation of culture and society. Rather it ultimately judges such questions performatively, on the basis of efficiency for the system and rewards for the profession - the fact that Fish unfortunately suppresses.

Professionalism, in other words, is tantamount to excellence. It is the tendency toward ideological indifference and capaciousness that makes it so popular today as a conceptual bottom line; it permits the illusion to those still sympathetic to Martin's way of thinking that the university remains bound by an ideological or social mission - simply because it does not explicitly disallow it. More recently, professionalism has also come to stand for an enlightened pragmatism and skepticism of ideology and culture. All along, however, it is bureaucratic and capitalistic imperatives that ultimately regulate practices. In fact, the changes that professionalism brought to the university and the department were first justified in bluntly bureaucratic and capitalistic terms - as enhancing bureaucratic administration and efficiency.

\section{'A threatening situation'}

In Martin's university, the fallacy of mimesis or representation inhered: literature earned its distinction from other writing insofar as it represented the culture's constitutive ideals and exemplified the most transparent deployments of language. But by the late sixties, a tide of factors - the performativity of the core, encroaching professionalism in the university, and changing student demographics — had to have made it clear that English would not be able to continue in good faith to make the kinds of confident, representative claims for literature that had justified its study from the beginning. Guillory's analysis also dates about now the burgeoning of the professional-managerial class, a class steeped in the professional ideology and which as a result "no longer requires the cultural capital of the old bourgeoisie" (45). In this context, the low morale and faculty infighting, notorious in the English department during the seventies and eighties, become easier to understand: they stemmed from the obvious threat to the career and identity of the English professor. As J. Hillis Miller has acknowledged recently:

The loss of confidence in the possibility of justifying a syllabus on the grounds of its objectively verifiable representative status is almost as much of a disaster for those trained in the old ways of teaching literature (me, for example) as would be, for citizens of the United States, a loss of confidence in the power of their elected representatives to represent them. (30)

Far more than just the loss of an intellectual argument, the change Miller refers to represented a cataclysm largely because it delegitimized the authority of the literature professoriat. It opened up the question of the legitimacy of English studies in the same way that a bribery scandal would destroy the legitimacy of elected officials to make policy.

It is not surprising, then, that a sense of malaise, if not disaster, pervades the portrayals of the faculty in two comprehensive department reviews — known as the "Herrera 
committee" report, undertaken in 1974, and the "Hemenway report," in 1982. Both document widespread faculty dispiritedness and disagreement over department goals. $\underline{\mathbf{2 0}}$ Nor is it surprising that both reports call attention to a professional and personal schism dividing literature specialists from composition specialists - what one report declares as a source of "deep resentment" (Lorince 22) and the other describes as "a threatening situation between 'two camps' " (Herrera 8). The Herrera committee also notes a department "class system" and atmosphere of "academic snobbery" (2) that alienated younger faculty members from older ones. None of this is surprising for two reasons.

First, composition as a department function undermined the cultural authority that the literature camp had relied on, supplanting it with a more rational authority, one which frankly valued practicality above the higher purpose of forming cultured subjects. In the words of the Herrera committee, composition "supports the pedagogical philosophy of the teaching of skills, i.e., writing" while literature insists on "analytical critical appreciation of literature" and "the ability of the student to think" (2). Where the literature camp stressed faculties of the personality, composition taught the development of specific skills, which were, not coincidentally, far more commensurate with market valuations, specifically in their relation to bureaucratic administration. $\underline{\mathbf{2 1}}$ This alone would not sow so much discord were it not for the second factor: the fact that, as both reports make unmistakably clear, composition had by this time become a rising force in the department. The Herrera committee, for instance, contends that composition "must become an integral

20. Both reports survey faculty members and students on a variety of issues. The Hemenway committee begins its discussion of faculty opinions on morale (Lorince 22-4) with the blunt statement: "The morale of the faculty in the English Department is not good" (22). It continues, "[E]ach committee member believes that the morale in the English Department is worse than that in his or her own department" (23). With regard to its discussion of department goals (1-2), it concludes that the faculty differs with the chair and administration over proper priorities. Specifically, faculty members complain that, in terms of awards and recognition, the administration values research more than teaching. Herrera identifies low morale and the confusion and disagreement about department goals as the two of the most pressing problems facing the department, and the report begins with four pages of survey responses reflecting negative opinions on morale and goals (1-4).

21. Guillory notes that although the professional-managerial class may no longer value the hallmarks of national culture, the nation-state "still requires a relatively homogeneous language to administer its citizenry" (263). This fact has everything to do with the institutional success of composition. "[T]he new institutional significance of composition marks the appearance of a new social function for the university: the task of providing the future technobureaucratic elite with precisely and only the linguistic competence necessary for the performance of its specialized functions" (264). The university recognized this new function for English frankly and early on. About the time the core curriculum was instituted, an English Proficiency Exam was put in place too; but the arguments for it avoided, and even scorned, lofty appeals to culture, instead citing the exigencies of professional life. In 1965, the Faculty Senate committee convened to review the exam wrote: "[T]his committee, composed of faculty members from widely diversified disciplines, is concerned with good English, not as an adornment or an end in itself, but as a fundamental tool, essential to the business of educated man" (English Proficiency Board 2). 
part [of the department] on an equal footing with the literature courses" (68). Reflecting composition's new prominence, the Hemenway committee reports that one group of faculty members that believed English should be grounded in "humanistic values" also lamented that "the primary mission of the Department is of necessity 'literacy trainings' " (Lorince 62).

To interpret the rise of composition and concomitant decline of the literature camp as politically progressive developments, as "ideological" in that sense, would be to rationalize them for the sake of a good conscience. Composition simply proved more conducive to "scientific management ideologies" and could bracket properly political questions. Unlike the study of literature at that time, composition could be understood and evaluated as a methodology: grounded in quasi-scientific criteria and readily commodified in research and iterative skills. The Herrera report, for instance, makes it clear that the difference between composition and the literary conception of English had nothing to do with matters of social justice or attention to student needs or any external social criterion (excluding the market, of course), and everything to do with internal bureaucratic efficiency:

People in the area of literature define goals in a much different way than do those in composition and rhetoric. The literature people talk about developing insights and understandings[,] with "involving" students in developing appreciation of ways of life. To provide appreciation and criticism of literature, to think critically and interpret accurately [sic]. Efforts to obtain more specific lower level objectives or specific objectives stated in behavioral terms are difficult to come by. In contrast the composition and rhetoric area seems to lend itself to a more functional analysis, and faculty in that area were able to develop much clearer goals and more specific objectives which could be clearly identified. Therefore, it becomes much easier for the administration and/or those working in curriculum development to develop rationales, programs, courses, etc., and support for such as the composition program area. (8)

Lest this be mistaken as a purely administrative sentiment, it should be noted that the committee was composed of four Arts and Sciences professors and one from Education. By their lights, university support and program development hinge crucially on an academic program's administrative fungibility. Literary training at the time might have entailed perpetuating certain heinous inequalities regarding women and minorities and lugged other dubious political baggage; but its unforgivable offense was that as an academic program it could not be distilled into consistent, specific, "low-level" objectives. The "behavioral" aspect of literary training in itself warrants no comment in the report; it is the obliqueness of its "terms" that the committee deems problematic. Composition, in contrast, dodges such pitfalls through its emphasis on developing skills, which admit of generally transparent standards of competence and technical ability. (Hence also the institutional viability of creative writing, a skills-based field otherwise deeply invested in the literature camp's humanist ideology that has nevertheless expanded in the department as traditional literary training has faded.)

As the pendulum swung to composition, it also appears to have swung to published 
research. Each accommodated an increasingly assertive bureaucratic university structure by submitting in similar ways to the first rule of corporate existence, the rule of exchangeability. By 1984, the time when English could successfully appeal to abstractions like "liberal education" and "cultural heritage" or even "democracy" had long since passed. Research, like composition, allowed the department to rephrase its justification in terms that ultimately proved more conducive to commodification.

It is obvious, after all, that the university's valuation of scholarly productivity skyrocketed at some point in the mid-seventies. The department's poor record of publication throughout the sixties and early seventies makes it apparent that research output had a low priority then. $\underline{22}$ But both the Herrera and Hemenway committees stress the urgent need for increased scholarly publication. The Herrera report concludes: "Ultimately the greatest necessity is that the English faculty do much more in the way of scholarly publication" (42). The outside consultant hired by the Hemenway committee, University of Kentucky English Professor Robert Hemenway, identifies the shortage of publications as "[t]he major weakness in the department" (100). It is a universal and unquestioned assumption in both reports - one held by the writers as well as by the interviewed faculty members - that the English department's success can and should be measured to a much greater degree by its publication output. When both reports are not subjecting research productivity to a kind of quantitative boardroom measurement, $\underline{\mathbf{2 3}}$ they instead factor it as a source of national prestige or prominence, as in "the department generally has not published a work of excellence which would cause it to acquire a national reputation" (Hemenway 100) or "The English faculty must collectively pursue excellence as scholars and teachers by producing research and creative work of national and international distinction" (Hemenway 128). Here publication corresponds to an abstraction that unmistakably implies basic surplus economic value for the university through the possibility of attracting more students and grants. $\underline{\mathbf{2 4}}$

It must be pointed out that both reports do consistently justify research as essential to keeping education vital; and both at least suggest that publication is essential to main-

22. According to the Herrera report, in 1974 the faculty of 59 was responsible for the publication of six scholarly books, five of which had been published before 1968 and four of which were by one person. Additionally, it had published 19 articles in "quality national and foreign publications," 12 of which came before 1968 (43). By 1982, the faculty, now numbering 52, had added four faculty-authored books and four edited or co-edited by faculty, along with 39 more articles in national and international journals (Lorince 43).

23. For example, Hemenway introduces a simple mathematical standard for the department to follow, one grounded in the competitive premise fundamental to capitalist relations: "Only about thirty percent of the faculty appear to be actively involved in research, a figure which can be contrasted with the normal Ph.D. granting department, where the percentage is usually close to ninety" (101).

24. Nineteen eighty-two may seem early for grantsmanship, but Hemenway demonstrates that outside funding loomed large as a budgetary factor at this time, lamenting in his discussion of research inadequacies that, "Very little extramural funding for research has ever been sought or granted" (101). 
taining a crucial national and international forum for new ideas, a forum which it is all scholars' responsibility to help maintain. That sentiment seems buried, however, beneath code words like "prominence" and "reputation" used in justifying and evaluating research by the financial rewards it brings universities, departments, and the most select researchers. Precisely such rationalizations impel universities to strive constantly to expand - to acquire more students, more teachers, more money, more real estate - as if they were businesses.

In the history of WVU's English department, few episodes illuminate this mentality in action better than the "previous life" of the Ph.D. program. It might seem probable that the creation of the doctorate in 1973 is responsible for the publication push. But the opposite is far more likely: the doctorate is instituted and promoted as a direct result of the new cache of research - as an imposed impetus to do more research and as a necessary step to becoming recognized as a department and university that engages in significant research. There is not much evidence to indicate that the department created the program in response to overwhelming student demand or a request by the state or any other pressing institutional or social need; on the contrary, the program fails to meet "academic standards," attract qualified students, and to generate a satisfactory amount of published research and institutional support, and for these reasons is closed down in $1985 . \underline{25}$

\section{The advent of theory}

The split between the literature and composition camps would not heal, but rather widen until the literature group shrank into an ineffectual minority. A severance package in the mid-eighties involving five older professors (then equal to about 10 percent of the full-time faculty) hastened the rout, as did the selection of Rudolph Almasy as department chair, in 1984. But the department under Almasy did not, obviously, abandon the study of literature in favor of composition. Rather it began, through a campaign of hirings spearheaded by Almasy, to turn its back on the intransigently humanist conception of literature that had undergirded the literature camp's arguments. In its place was a conception more in tune with scientism and bureaucratic administration, namely, literary theory.

In its earliest phase on American campuses, before its arrival at WVU, theory was understood as the systematic linguistic analysis of literature, as a methodology for "theo-

25. The University Graduate Council actually gave 15 reasons for suspending the doctoral program, but they can be categorized into four areas in need of improvement: "excellence," the quality of students, the quality and amount of research, and the amount of support. In terms of excellence, for instance, the program must "upgrade academic standards" and "guarantee the pursuit of excellence." As for student quality, the program has to "raise admission requirements" and "implement a recruitment campaign." Regarding research, the program is required to "upgrade the research reputation of the graduate faculty," "insure that only the most accomplished faculty members guide doctoral candidates," and "make the Ph.D. a training ground for active scholarship." Regarding support, the council demands that "graduate assistant stipends [be raised] to level that makes them nationally competitive" and that the graduate faculty reduces its teaching load (Almasy 1989 5). 
rizing" literature by laying bare its constituent linguistic parts.26 At this point the "market" in traditional humanism had crashed, to borrow Guillory's economistic terminology, while shares of professionalism surged. The ensuing debate over humanism and the canon within the literary institution resulted from "a more historically significant split between two kinds of cultural capital, one of which is 'traditional,' the other organic to the constitution of the professional-managerial class" (45). Theory offered English departments the compromise of blending the two kinds of capital: it transformed the study of literature into a kind of technology. Such a compromise entailed no retreat from literature's indispensable claims to a constative or essentialist basis; it merely relocated the objective value of literature from its themes and ideals to its language.

This point figures prominently in Guillory's discussion of theory as a key symptom of fundamental disciplinary problems involving the category of "literature" itself. "[T]he syllabus of literary works always demanded an essentialist concept of literature to ground it," he reminds us. "Theory replaced the 'humanistic' thematic of literature with an equally universalizing, if antihumanistic, thematic of language; the important point is that theory belongs to the long-term historical project of providing a rationale of the literary curriculum that would effectively establish a syllabus of study" (262).

What determined theory's makeup, what accounts for its characteristic antihumanism and "linguistic turn," was simply the new labor conditions that came to define work in the university and other workplaces of the PMC, i.e., the influence of scientism and the professionalist ideology: "The adjustment of critical practice to new socioinstitutional conditions of literary pedagogy is registered symptomatically within theory by its tendency to model the intellectual work of the theorist on the new social form of intellectual work, the technobureaucratic labor of the new professional-managerial class" (181). To put it another way, theory reaffirms a literary essence, modernizing (instead of abandoning) the cultural mission by adding a scientific, professionalist veneer; theory corrects the means by which one decides what is literary by spurning a stridently non-scientific approach, hermeneutics, for a more ostensibly scientific one, linguistics.

This reformulation, however, left the literary institution without a central social function. Fearing irrelevance, theory's practitioners would take on the mantle of a political movement by challenging humanism's exclusionary ideology instead of its truth claims. It was at this stage in theory's development that department began to embrace it. Thus Almasy attributes the initial rise of theory at WVU to the impact of feminism:

Feminism was the first force [in bringing about theory]. By eighty-four, the department was nearly entirely male and white, and they were not willing or able to

26. Coming to grips with a firm definition of "theory" is, of course, another thesis entirely. But it seems to me that if nothing else, literary theory is a means of reconceiving or overcoming "literature" by focusing instead on language, a domain that can be more properly "theorized." A turn to linguistic analysis characterizes all of those strains of theory - formalism, structuralism, and deconstruction - that first constituted the "theory" monolith, a theme that Paul de Man makes his chief argument in Resistance to Theory (1986): "The advent of theory, the break that is now so often deplored and that sets it aside from literary history and literary criticism, occurs with the introduction of linguistic terminology in the metalanguage of literature" (8). 
do anything in the way of research. The feminist movement was the key to exposing that. Feminism began to slap it in the face, to really bring home the fact that American literary studies are political. $\mathbf{2 7}$

To regard the humanistic values of canonical literature as somehow universal and unquestionable, as the department had done, implicitly defined the universal subject as white and male. And to regard literature as rarefied and resistant to research served only to insulate the men who taught it from questions about their abilities and dedication as teachers and scholars. Feminism made all this apparent. By turning to theory, the department responded by seeking out an alternative to grounding itself in humanism. As a result the humanist grounding and hegemony of the canon started to fade; the humanist syllabus began to include contemporary writers and theoretical writings as well as "marginal" writers from the past. And eventually the department would abandon the master's comprehensive exam, a test that had established knowledge of traditionally canonical texts as the standard of competence within the department.

Unlike the core curriculum, which responded to cultural education's performativity by baldly reaffirming it as constative, theory here stands as an honest attempt to work around the suspect implications of Martin's narrative. But this attempt also ends up reaffirming Martin's vision, even though it is articulated as a direct challenge to it. Instead of breaking with the fallacy of representation, the critique of literary study that Almasy alludes to would simply redefine it as political representation: by democratizing the literary syllabus of study, it imagined itself restoring literature's hoary claims to representativeness.

Two related accounts are worth citing at this point. First, there is Stanley Fish's prominent argument against "foundationalism," or the application of theory so as to "ground inquiry and communication in something more firm and stable than mere belief or unexamined practice" (1989 342). Among the foundations that have been used in the past, Fish includes: "God, the material or 'brute act' world, rationality in general and logic in particular, a neutral-observation language, the set of eternal values, and the free and independent self" (343) — to which could be added the nation-state and national culture. Peter C. Carafiol does just this in his analysis of contemporary American literary studies, The American Ideal (1987). Building on Fish's "antifoundationalism," Carafiol points to evidence of a foundationalist fallacy behind much revisionist, emphatically political scholarship by Americanists. Determined to coherently narrativize American literary history and legitimize American literary studies as a discrete professional and socially relevant activity, Americanists have found common cause in attacking the "fat targets of aesthetic formalism, sexism, and racism" (14) — attacks which provide their work with a precious theme and social relevance. Carafiol writes: "Political commitment distracts from doubts about the integrity of the field that have arisen since scholars have lost confidence in the 'National Character' that initially justified American literary studies" (14). In going down this road, Americanists have resurrected the traditional project of Ameri-

27. All quotes and paraphrases from Almasy were recorded in an interview held on May 23, 2000. 
can letters, that of articulating the "American Ideal," the nationalist myth, which is merely reconceived now in terms of social justice and "that fundamental tenet of the American myth, a diversity of views" (16). Far from valuing diversity, such attempts to redefine "America" and "open up the canon" merely "legitimate the power of consensus and, thus, the status quo" (36). Therefore, Carafiol argues, "we must recognize our susceptibility not just to the 'theoretical urge' for an explanatory umbrella [pace Fish] but also to the positivist urge that makes us want to make unjustified claims about the connections between texts and something purportedly more real, to culture" (37).

Like humanism, linguistic theory and, later, the cause of social justice were deployed to justify the study of literature as an academic domain with a constative basis, as a collection of texts with "connections to something purportedly more real." To view literary theory as somehow politically progressive is to view literature as still capable of redeeming students and readers, as a tool for forming symmetrical characters according to a supposedly updated and more egalitarian definition of character.

By this logic, the department could justify maintaining throughout the eighties and nineties essentially the same curriculum, based largely on conventional periodizations, national categorizations, and traditional genre classifications. And it has adhered to the same field-coverage model for hiring, oriented more or less to traditional specializations: early and later American, early and later British, Medieval, Renaissance, Romanticism, etc. It was the canonical content of the courses and concentrations that came in for criticism, not the organizing principles behind them. So in principle literary theory proved consistent with the teaching of historical surveys of American and British literature. In fact, these surveys remain the curricular bases of the undergraduate and graduate programs today. $\underline{\mathbf{2 8}}$ It would not be going too far to say that the British and American categorizations remain the primary organizing principles of the entire department: nearly every full-time professor position, with the exception of the linguistics, composition, and creative-writing spots, are defined in job announcements as well as in common parlance by national and historical designations. Such courses and categorizations necessarily imply a legitimate, representational relation between certain texts and the nation-state. They remain inextricably bound up in the defunct idea of national culture - ingrown, like the core curriculum, around a "core" that no longer exists.

\section{The master's comprehensive}

If one department episode epitomizes the tenacity of the idea of cultural education, it would have to be the demise of the master's comp. Here a fortress of cultural education and the literary camp fell under attack from theory, but in the end was merely hollowed out and left standing.

It was the intent of the master's comprehensive to preserve the tradition of national culture by ensuring that students master the constitutive themes and concepts of the cul-

28. Of the 18 department hours specifically required for undergraduate majors, 12 must be in traditional British and American historical surveys. Meanwhile, most graduate courses are classified by nationality, and the department's Ph.D. fellowships require concentration in either British or American literature. 
ture. Consequently, the exam required students to demonstrate mastery of a certain domain of cultural knowledge composed of standard written English and canonical literary history. The exam posed questions meant to "address the student's knowledge of primary texts" (Department 1986 3). The questions corresponded to nine periods of literary history and the categories of "genre," "author," "topic," "Shakespeare," "literary theory," "composition and rhetoric" and "poetry explication" (2). Such a structure implied an unassailable integrity for literary periodizations like "Medieval" and "Renaissance" as well as for certain literary figures, forms, and issues - which made comprehensive knowledge of them both possible and desirable. The confidence in such a cultural and literary organicism is probably most evident in the requisite "poetry explication" question, the only required category, which assumed a necessary kinship between literary knowledge and a particular norm of reading.

Toward the end of the eighties, a consensus had built up in the department against the exam. One of the loudest criticisms held that the exam's emphasis on primary texts had become suspect politically. Essentially, the exam's opponents recognized that the questions blatantly perpetuated the humanist ideology. According to Almasy, "It was decided it was a problem politically, canonically; it [eliminating the exam] became politically the right thing to do." After a contentious debate, the graduate faculty supplanted the exam in 1990 with a preliminary test for doctoral students that was more balanced between primary and secondary texts.

Yet as a concession to the vocal proponents of cultural education and literary comprehensiveness (the literature-camp holdouts), the department's current coursedistribution requirements for master's students - "core," "author-topic-genre," and "seminar" - were implemented at this time. Such course classifications echo unmistakably the same kind of representational logic animating the exam — most obviously in the "core" classes, composed primarily of historical surveys. But note the difference. By eliminating the exam, the department abandoned the standard of mastery of cultural knowledge, the kind of meaningful and unambiguous standard Martin would have endorsed. Yet instead of eliminating it entirely and breaking completely with cultural education, the department replaced the standard of cultural knowledge with a standard of bureaucratic competence - a checklist of courses in certain periods and genres that replicated cultural knowledge, so that the whiff of it lingered. The course-distribution setup might in principle signify cultural knowledge, just as the core curriculum might; but in practice both would stand for nothing so much as labor time. Like the core, the department's response to the master's exam replaced the idea of a unified culture with a quantified one.포

29. In fact, in its first few years the doctoral exam that replaced the M.A. comprehensive resembled in several ways the same test. From 1990 to 1994, the ratio of theory-oriented (i.e., secondary) books to primary, "canonical" texts was uniformly three to seven. (The lists of texts that figured in the master's exam are no longer available, but since it did feature a "literary theory" component, it can be assumed that its percentage of primary texts was less than 100 , and therefore not much different from that of the predoctoral exam.) By 1996, that ratio had risen to 12 out of 16. Furthermore, the doctoral exam also aimed to replicate the M.A. exam's comprehensiveness, but in a novel way: it was prefaced by a semester-long course, made up of classes with each »» 
While this failed to solve the exam's social-justice problems, it did solve a pressing administrative problem. Almasy and his predecessor, Elaine Ginsberg, who was also instrumental in the exam debate, both agree that the exam's fatal flaw was actually that too many students were failing. $\underline{\mathbf{3 0}}$ From 1985 to 1990, just under 60 percent passed. $\underline{\mathbf{3 1}}$ "The students we were getting were less well-read," Almasy says. "They simply couldn't handle it [the exam] any longer." He characterizes the difference as a generational shift and points to the element of literary comprehensiveness in his own training as a historical contrast. But more than just a generational difference, this transformation seems entirely consistent with Guillory's description of the emergence of the professional-managerial class on campus. To the PMC, national culture carries much less weight. Fully integrated into mass culture, it derives its status and power from the acquisition of technical knowledge and professional credentials, not "the cultural capital of the old bourgeoisie"; that tradition tends toward estrangement rather than inspiration. Facing the PMC head-on would have meant facing the potential obsolescence of English as a discipline and profession. Therefore, the department met it half way - blurring its definition of culture and literature while accommodating master's gatekeeping to bureaucratic-professionalist standards of competence based on labor time. The dubious integrity of testable cultural knowledge gave way to the expedience of bankrupt course distributions.

The exam debate provides a perfect illustration of Readings's argument that, in a university of excellence, the issue of teaching devolves into a matter of how to manage knowledge, not how effectively it will reproduce culture or political consciousness or some other end. He writes that, "The administration of knowledge is, of course, the only point at which anything like a question of content enters: the question of what knowledge is to be managed by teachers and administered to students" (152). Though phrased as a question of content, the exam debate ended up being resolved through a change in administration, with no material change to content. The department would admit as much in its own justification of the course-distribution requirements, describing their purpose in 1994's Board of Trustees report as serving "the goal of breadth" (Oderman 2). The "goal of breadth," a synonym for comprehensiveness, would seem to present as great a political problem in the classroom as it did in the exam; but "pursuing" it in the classroom would prevent the disastrous administrative results of actually pursing it (namely, a 40 percent failure rate). The department could claim English as a discrete, objective discipline (i.e.,

»» graduate faculty member - thus blending the issues and authors of each professor's focus area into one exam, and as such one discrete, testable field of knowledge. So instead of conceiving of the canon as a "representative" universe, as the M.A. exam had done, the predoctoral exam seems to have invested the faculty with representative power. And, the field-coverage model being what it is, the faculty presumably stood for the canon, but at one remove. The exam was never explicitly explained in these terms, but it would be difficult to justify its makeup otherwise.

30. All quotes and paraphrases from Ginsberg were recorded in an interview held on May 30, 2000.

31. Of the 67 master's students who took the exam from the spring 1985 term to the fall 1990 semester, 40 passed. Of those 40, five failed on their first attempt (Department 1990). 
one in which breadth of learning, and not just pointless eclecticism, was possible) and point to the "real progress" of students in mastering it.

It could also do what it wanted in the classroom, and faculty members commonly defend the course distributions by emphasizing this. Ginsberg, for example, stresses that the "shape of the courses" has gone through dramatic transformations since the end of the exam. "Even those that look like historical surveys have changed considerably. They're all called the same, but their focus has changed, even the focus of the surveys themselves." All very well, but also very similar to the core curriculum: structured to advance cultural education, but carried out in ways that undermine it. By preserving the structure of cultural education, the core has preserved all its assumptions, all its foreclosures of thinking; that's what structures are for. Theory has similarly preserved the literary argument and fallen prey to its representational logic. The question remains, then, of how to structure English education as something other than an exercise in cultural education. 


\section{Chapter 4: The University in Ruins}

The department's experience with theory and the M.A. exam, as well as its changing attitude toward composition and research, represent the kind of rationalizations that contribute to what Guillory calls the "institutional dysfunction" of the discipline. They allow the department to repress difficult questions about disciplinary boundaries, aims, and value. The concessions to professionalism that they involve - the commodification of scholarship and imposition of accounting standards on gatekeeping, for example may look innocuous enough, and some are even salutary; no one could argue, after all, against providing students with employable skills related to the discipline. But if the department continues to organize itself around reinventions of Martin's cultural mission, then the administration will impose more of its professionalist evaluations and judgments. Because right now administration and accounting provide the only basis for making judgments in the department. For example, in its most recent program review, the department can point to nothing more than the "literary, linguistic, and cultural heritage of anglophone nations" as its reason for being. $\underline{\mathbf{3 2}}$ Under professionalism, however, cultural heritage simply ceases to obtain, unless it can be reinscribed commercially as tourism or intellectual property. The department may continue to find palatable ways to construe the old model to its purposes - to teach surveys or the "classics" subversively — but the old model is breaking down. $\underline{\mathbf{3}}$

32. The department's 1999-2000 Board of Trustees Review lists the following five goals for the Ph.D. program:

(1.) to build on the broad foundations of the M.A. degree's focus on the literary, linguistic, and cultural heritage of Britain, the United States, and other Anglophone nations; (2.) to develop fluency in the critical discourses of the profession; (3.) to develop professional competency in three specific, interrelated fields of research (as defined by the Exam for Admission to Candidacy); (4.) to develop research, writing, and analytical methods necessary for professional success; (5.) to develop skills and experience in preparation for teaching English on the post-secondary level. (Conner Ph.D. Review 1)

Notice that all but the first goal are internal to the profession; they function within the closed system of the profession itself. Only the appeal to heritage refers to an external justification. The master's program report is at an even greater loss to articulate aims of the program that go beyond the department itself. According to the report, the hypothetical termination of the master's program would have three results: it would damage the viability of the Ph.D. program, cost the university valuable visibility, and require new spending for the hiring of additional faculty to teach freshman composition - even with savings from the cutbacks (i.e., fewer graduate courses taught) funneled back into the department (Conner M.A. Review 12). A comparison of 1999-2000's 21 M.A. graduate teaching assistants' academic-year salary, $\$ 6,760$, with the WVU average for instructor-level faculty, $\$ 33,999$, illustrates the significant efficiencies that the master's program provides.

33. The fate of WVU's Classics department might be symptomatic of this. Once integral to the undergraduate curriculum, reflected in the fact that Martin himself was a professor of Greek, it now exists only nominally — granting no degrees and allotted just a handful of classes. 
It bears repeating that this breakdown deserves no tears. But it represents nothing short of a revolution in the way universities will be thought and run, with all the struggles over power and resources attendant on revolutions. And the department, to extend the metaphor, remains decidedly passive if not loyalist. This does not mean that it needs now to embrace excellence and accounting. But it does have to find ways to resist excellence that do not at the same time reinvoke the old model. The advocates of professionalism have repudiated Martin's cultural foundationalism with impressive force; but they do so only to install a completely closed professionalist system, one which submits questions of value to a wholly internal administrative authority - a system totally in keeping with accounting and excellence. The gambit of theory, on the other hand, has seemed to circumvent an excellence-oriented, detached administration through appeals to linguistic essentialism and social justice; but it does so in the tradition of Martin, assuming a constative basis for pedagogy and research.

Even Guillory in the end would resurrect national culture. He concludes by arguing that, since English education has historically been a process of transmitting cultural capital, English educators owe it to their students to keep that capital properly "cultural." Strangely, they don't owe it to students to move beyond the dubious and timeworn institutional arrangements whereby cultural knowledge enhances social and economic standing. In Guillory, the regime of national culture rules supreme - and democratically but it has become corrupted by class ideology and the influence of the market; therefore, it is educators' responsibility to redemocraticize access to the canon and canonical status by stripping aesthetic, canon-forming judgments of their socioeconomic chaff, so that only the cultural wheat remains. He writes: "A total democratization of access to cultural products would disarticulate the formation of cultural capital from the class structure and from the markets" (337). Cultural products would be "judged (and also contested) on aesthetic grounds... not on the basis of their inaccessibility" (339). Not only would purer aestheticism legitimize education, Guillory suggests it would enable cultural works to reawaken the sense of cultural identity in students. "In a culture of such universal access," he concludes, "canonical works could not be experienced as they so often are, as lifeless monuments.... Socializing the means of production and consumption would be the condition of an aestheticism unbound" (340). He presumes, in other words, that only class and economic factors mar the canon's claims to legitimacy — that an aesthetic or cultural unity still abides. But if cultural capital remains loosely tied to some base of compelling cultural unity, how was it entangled in the market and class ideology in the first place? It is a dubious and minority "aestheticism" or "nationalism" that needs disarticulated from socioeconomic factors, that futilely protests the advance of a truly global market.

In contrast to such half-measures, Readings would reconceive practices in more fundamental ways. But his response does not entail the formulation of yet another mission to modernize and supplant Martin's; rather it means finding "a new language in which to make a claim for [the university's] role as a locus of higher education" (125). And that entails, in short, the willingness to proceed without a mission, without a language that weaves together disparate university activities into some imaginary teleology, like the formation of a national subject. "Being smart in the present situation requires another kind of thinking altogether, one that does not seek to lend work in the University a unified ideological function" (125). To appeal to a mission and orient activities to it, is really 
to defer to the authority of an idea. Missions imply givens; one synonym Readings is fond of using for them is alibi. The first condition of resistance to excellence, then, is to function at last without alibis.

It is also in essence the last condition. As Readings acknowledges, and as I suggested at the outset, the reign of excellence is not without its advantages. Its "dereferentializations" — that is, its erosions of specific referents for keywords like culture — pave the way for a university practice that does not require modernist certitudes to perpetuate or justify itself. Its erosion of traditional humanism in the university — chiefly the result of market imperatives - deserves the credit for integrating women and minorities into a nominally exclusionary, humanistic institution. The process of dereferentialization hollows out such hallowed ideas, and opens up new spaces inside them. The problem with it is that, like all bourgeois revolutions, it seeks to impose the exclusive rule of exchangevalue on those new spaces. Therefore, something quite similar to excellence will do the trick, something that melts solid meanings into air, as Marx describes capitalism doing so long as its dereferentializations are not carried out in order to further consolidate capitalism, nor done under some alibi that would conceal the fact that it acts for capitalist expansion.

What Readings proposes, with great semantic scrupulousness, is not something at all, but rather a name. What is most important, he argues, is that universities remain places where thinking goes on, as opposed to training or the applications of thinking; and faith in "things," or ideas with reliable and realizable meanings, is ultimately what reduces "thinking" to training — as the circumscribed process of realizing and replicating "worthy" ideas. Therefore, teaching and research should not revolve around an idea but around the empty referent of a name, the "name of Thought." Readings is quick to emphasize that his phrasing and capital $\mathrm{T}$ are not meant to confer the mysticism of religion; such markers are designed rather to avoid the confusion of this referent with any single signification. "The name of Thought precisely is a name in that it has no intrinsic meaning" (159). As merely a designation, a name cannot have truth-value, thus it cannot foreclose or constrain discussion, as missions do.

Readings's phrasing consciously alludes to Heidegger's What Is Called Thinking? which situates "Thought" as a calling or vocation consisting of questioning that questions even itself. "What is crucial" about Heidegger's notion, Readings says, "is that Thought appropriates the subject, not vice-versa.... To be called to think is to enter thinking without knowing in advance what it is that is to be Thought" (222n10). Thus like excellence Thought has no fixed content; but unlike excellence it makes no secret of that fact, thereby escaping the constraints that excellence imposes on thinking. Thought "does not masquerade as an idea," and as a result it "does not function as an answer but as a question" (160).

The effect of this reconfiguration is that teaching and learning become preeminently ethical instead of teleological activities — organized around a commitment rather than a belief. $\underline{\mathbf{3 4}}$ Such a commitment seems nascent in the oppositional rhetoric of WVU's stu-

34. A belief can be finally accepted or arrived at (or rejected); but a commitment allows no such closure, thus it frustrates the teleologies and temporality (and often the rush) imposed on degree programs: the institutionalized fictions of "graduation" and "mastery." Thus Readings reconceives the university experience as a "time of study," not a journey of emancipation or mastery. 
dent protestors, who knew that Martin's narrative of students-growing-into-subjects had lost its purchase, but who also knew that their professors and courses of study still exercised some claim on them that exceeded professional credentialization; having outgrown Martin's vision and spurned the mercantilization of learning (what Mike Connor called "mass education"), they found themselves no less bound to the university and to learning. The commitment to learning exercises something of an ethical hold — an obligation to otherness, the deeper since it can never be fully discharged. Those who enter into the pedagogic relation, Readings argues, "are caught in a dialogic web of obligations to thought" (145). That is to say: teaching and learning do not take place in order to transform the student into the teacher, or some other fully formed subject (or product) - an Enlightenment narrative designed to make students autonomous, thus free from obligations. Rather, teaching and learning take place in order to evoke obligations — not just to each other but to the referent of study, the "study topic." In terms of linguistics, each pole of the pedagogical conversation - the sender, the addressee, the referent and the signification - represents an other whose differences cannot be liquidated; teaching functions to impart the weight of those differences rather than integrate them through some third term like "culture" or "socialism."

This might sound like a subtle evasion of politics, but what it actually articulates is a commitment to the idea that politics can never be evaded. Both right and left have posed politics as the forum for redeeming human relations, for achieving final utopian resolution of historical conflicts and differences. Such a view of politics implies the eventual reconciliation of everyone to a certain idiom of self-representation; it implies, that is, the end of politics, in the revolutionary moment of the proletariat's emancipation or republican dream of perfect political self-representation - no matter how far off such agreement always seems. Readings, drawing heavily on the political writings of Jean-François Lyotard, abjures the homogenizing teleology of consensus as chimerical, even "terroristic," and certainly facile. Politics instead becomes the site of confronting and exploring precisely those conflicts that can never be resolved; it seeks just these political deadends as its "ends." Its ground-zero is not, therefore, the parliament or the appeals court, but the give-and-take of the classroom. The goal of education ceases to be emancipation; emancipation is rendered forever impossible - itself an evasion - in the sense that there are differences that can never be overcome. To put it another way, we can never be made free by knowledge, since knowledge will only continue to reveal its interminably webbed contingency. On the contrary, education and politics function to further obligate us to others. In place of discovering truth is the practice of doing justice to others' differences.

Disintegrating, not integrating, more closely describes the desideratum of pedagogy:

There is some other in the classroom, and it has many names: culture, thought, desire, energy, tradition, the event, the immemorial, the sublime. The educational system seeks to process it, to dampen the shock it gives the system. Qua institution, education seeks to channel and circulate this otherness so that some form of profit can be made from it. Yet shock arises, since it is the minimal condition of pedagogy, and it opens a series of incalculable differences, the exploration of 
which is the business of pedagogy. (162)

The accounting logic of excellence cannot regard Thought with anything but hostility because Thought employs resources without generating exchange-value. It belongs to an "economy of waste." The challenge for academics, however, does not lie in overthrowing excellence and transforming the university into a palace or "gated community" of Thought; that, after all, would amount to a mission in its own right, and an extremely Quixotic one at that. The challenge is rather to find ways to keep Thought alive in an institution increasingly at odds with it: to coexist. Here the imagery of the ruins of Readings's title finds its significance. The university is a "ruined institution," and its ancient claims no longer speak to us. Yet we inhabit it much like contemporary residents of some ancient Italian city inhabit their ruins: distanced immeasurably from them but unable to sweep them away. Thus dwelling in such ruins involves great intellectual flexibility, if not a stabilized form of schizophrenia, which enables one to work in the space where one happens to be, without the need for an alibi that would harmonize the clash of circumstances. Dwelling in ruins involves an "institutional pragmatism," which grants first of all the fact of the institution and its ways but then looks for opportunities for Thought within that context.

One of the most difficult eventualities to grant the institution is that the current disciplinary framework cannot sustain itself for much longer. A consolidation of recognized English "concentrations," and eventually of humanities departments themselves, appears inevitable - most likely occurring under the aegis of cultural studies. The rationale on which the field-coverage and traditional faculty-system models have historically been based is inseparable from the cultural mission, and nothing in excellence says that such expensive and inefficient models must persist. Further, their elimination would not even necessarily represent a setback for Thought; insofar as English departments have invoked field-coverage robotically in shaping curricula and reaching hiring decisions, this model has functioned as an obstacle to Thought, as an alibi that forgives non-thinking.

Thought does require, however, that the questions unique to each discipline and field continue to be asked, and even become augmented by questions about discipline and field designations. Of course the real danger of "interdisciplinarity" is that such questions will indeed fade away with-out specialists to take them up. Thus Readings does not embrace a wholesale interdisciplinarity but rather a policy whereby the resources freed up by disciplinary consolidation are plowed back into a series of shortterm academic collaborations - investigations that form an "archipelago of minor activities." Such projects could very well bear resemblances to "degree tracks" or "specializations" in existence today, except that they would be disbanded after a certain period, regardless of their success, to be replaced by a new investigation. Being of limited duration, such projects would not evolve into mini-institutions that can afford to ignore the question of the disciplinary form of inquiry; the structure and terms of discussion themselves would become unavoidable topics for investigation, instead of givens that are protected by institutional clout, by the formidable if tacit legitimation that comes with a permanent place in the course rotation. "[D]isciplinary structures would be forced to answer to the name of Thought, to imagine what kinds of thinking they make possi- 
ble, and what kinds of thinking they exclude" (178). $\underline{\mathbf{3 5}}$

This one suggestion (there are others) conveys the quality of change Readings envisions. It throws into question, but without overthrowing, the infrastructure of course and degree "requirements," "core" curricula, and disciplines and fields. Most of all, it strips away the teleology of "graduation," which contrives a finishing-line or checklist for learning, a discourse of "mastery" and autonomy from further study. Life in the university may seem impractical or even impossible in such a scenario, doomed to endless wrangling over "project approval," grading criteria, and standards of competence (not to mention the ridicule from outside). But that criticism implies faith in the inherent goodness of practicality, or, worse still, faith in the inherent legitimacy of constructs like "degrees" and "graduation" — the belief that the "real work" of administrators and academics would be paralyzed by a running discussion about what constitutes "real work" or by any admission that academic standards are always provisional. Such criticism also belies the experience of this department, where for several years a scenario with similarities to Readings's has been playing out on one level of doctoral gatekeeping, the "book exam." After prolonged and often intense debates over standardizing the number and types of books on candidates' lists, it was finally decided that the lists would be arbitrated on a case-by-case basis. The department came to the conclusion that "the exam needed to be a constant negotiation," according to Ginsberg. This seems to me an exemplary, good-faith response to the changes unfolding in the university, a response which resists the alibis of cultural education as well as the expedience of excellence.

35. It is after his intense questioning of administrative and professional forms, in addition to academic forms, that Readings finds fault with Gerald Graff's injunction to "teach the conflicts." Graff would destabilize disciplinary authority by emphasizing its history of dissention; but such a challenge, admirable as it is, occurs under the auspices of an unchallenged professional and administrative structure. Thus Graff invites the institutionalization of "the conflicts" as a disciplinary field; in Readings's words, he "permits the determination and transmission of 'the conflict' as a unified object of professional discourse" (127). 


\section{Works Cited}

Almasy, Rudolph. Personal interview at Woodburn Hall, West Virginia University, Morgantown, W.Va. May 23, 2000.

_. "West Virginia University Doctoral Program Review." March 1, 1989.

Ammerman, Craig. "WVU Tense After Gas Quells Student Protest," The Charleston Gazette. June 8, 1970. Page 8A.

Bledstein, Burton. The Culture of Professionalism: The Middle Class and the Development of Higher Education in America. New York: Norton, 1976.

Carafiol, Peter C. The American Ideal: Literary History as a Worldly Activity. New York: Oxford UP, 1991.

Committee on Student Instruction. "Report on the Committee on Student Instruction." Annex II, [West Virginia] University Senate Agenda, Jan. 12, 1970. 1-4.

Conner, Patrick W. "1999-2000 Board of Trustees Review, West Virginia University, English M.A." Sept. 15, 1999.

_ . "1999-2000 Board of Trustees Review, West Virginia University, English Ph.D." Sept. 15, 1999.

Connor, Mike. "A Rationale for the Creation of a Genuine Educational Community at West Virginia University." [West Virginia] University Senate Agenda, Dec. 11, 1972. 4-12.

Conrad, Clifton F. and David J. Eagan. "Master's Degree Programs in American Higher Education." John C. Smart, ed. Higher Education: Handbook of Theory and Research, vol. 6. New York: Agathon Press, 1990.

— - Jennifer Grant Haworth and Susan Bolyard Millar. A Silent Success: Master's Education in the United States. Baltimore: The Johns Hopkins UP, 1993.

Core Curriculum Committee. "Core Curriculum Committee Report." [West Virginia] University Senate Agenda, Feb. 19, 1963.

Currie, Jan. "Introduction." Currie and Janice Newson, eds. Universities and Globalization: Critical Perspectives. Thousand Oaks, Calif.: Sage Publications. 1998. 1-13.

De Man, Paul. Resistance to Theory. Minneapolis: U of Minnesota P, 1986. 
Department of English, West Virginia University. "Procedures for M.A. Comprehensive Examination." March 1986.

Department of English, West Virginia University. "Summary of M.A. Exam 1985-90." 1990.

Doherty, William T. and Festus P. Summers. West Virginia University: Symbol of Unity in a Sectionalized State. Morgantown: West Virginia UP, 1982.

English Proficiency Board. Report of English Proficiency Board, April 2, 1965. Agenda, [West Virginia] Faculty Senate meeting, April 2, 1965. 1-6.

Fish, Stanley. "Anti-Professionalism." Doing What Comes Naturally: Change, Rhetoric, and the Practice of Theory in Literary and Legal Studies. Durham, N.C.: Duke UP, 1989. 215-46.

—. "Anti-Foundationalism, Theory Hope and the Teaching of Composition." Doing What Comes Naturally: Change, Rhetoric, and the Practice of Theory in Literary and Legal Studies. Durham, N.C.: Duke UP, 1989. 342-55.

Ginsberg, Elaine. Personal interview at Stansbury Hall, West Virginia University, Morgantown, W.Va. May 30, 2000.

Glazer, Judith. The Master's Degree: Tradition, Diversity, Innovation. Washington: ASHE-ERIC Higher Education Report No. 6, 1986.

Graff, Gerald. Professing Literature: An Institutional History. Chicago: U of Chicago P, 1987.

Guillory, John. Cultural Capital: The Problem of Literary Canon Formation. Chicago: U of Chicago P, 1993.

Heidegger, Martin. What Is Called Thinking? Trans. F. Wieck and J. Gray. New York: Harper and Row, 1968.

Hemenway, Robert. "Consultant's Report: West Virginia University English Department." Lorince, Frank et al. "Review Committee Report on the [West Virginia University] English Department." May 1982. 97-131.

Herrera, Frank, Edward C. Caldwell, John L. Carline, Urban Couch and Mortimer Levine. "Report from the Special Committee to Review the [West Virginia University] English Department." June 1974. 
Kant, Immanuel. The Conflict of the Faculties. Trans. Mary J. Gregor. New York: Abaris Books, 1979.

Larson, Magali Scarfatti. The Rise of the Professions: A Sociological Analysis. Berkeley, Calif.: U of California P, 1977.

Lorince, Frank, Dennis H. O'Brien, Helen Lester Plants, Richard P. Treat, and Lawrence R. Wheeless. "Review Committee Report on the [West Virginia University] English Department." May 1982.

Martin, Alexander. "Inaugural Address Delivered at the West Virginia Ag. College, Morgantown, West Va.: June 27, A.D., 1867." Morgantown, W.Va.: Morgan \& Hoffman, 1867.

Miller, J. Hillis. "Literary Study in the University Without Idea." ADE Bulletin 113 (Spring 1996): 30-33.

National Foundation on the Arts and the Humanities Act of 1965. Pub. L. 89-209. Sept. 29, 1965. <http://www.neh.fed.us/whoweare/legislation.html>

Oderman, Kevin. "1994-95 Board of Trustees Review, West Virginia University, English M.A." Sept. 15, 1994.

O'Harrow, Robert Jr. "Academic Research Under the Microscope." The Washington Post. Aug. 5, 2000. Page A01.

Ohmann, Richard. English in America: A Radical View of the Profession. New York: Oxford UP, 1976.

Readings, Bill. The University in Ruins. Cambridge: Harvard UP, 1996.

Rohwedder, Cecilie and David Wessel. "Once-Proud German Universities Are Now Failing by Many Measures." The Wall Street Journal. Feb. 26, 2001. Page A1.

Shumway, David R. Creating American Civilization: A Genealogy of American Literature as an Academic Discipline. Minneapolis: U of Minnesota P, 1994.

Stasny, John. "Issues and Goals of a Core Curriculum." Appendix B, "Report of the Special Committee for the Review of the Core Curriculum." Annex III of [West Virginia] University Senate Agenda for April 8, 1968. 1-2.

[West Virginia] University Senate Minutes, Dec. 11, 1972.

[West Virginia] University Senate Agenda, April 8, 1968. 
Veysey, Laurence R. The Emergence of the American University. Chicago: The U of Chicago P, 1970.

Weber, Samuel. Institution and Interpretation. Minneapolis: U of Minnesota P, 1987. 18B West Virginia Code. Sec. 1-1c. March 11, 1995.

West Virginia University. Statistical Abstracts / 1996-97. [Morgantown, W.Va.]: The University, 1997. 